\title{
Hanging on - lucinid bivalve survivors from the Paleocene and Eocene in the western Indian Ocean (Bivalvia: Lucinidae)
}

John D. TAYLOR

Emily A. GLOVER

Department of Life Sciences,

The Natural History Museum, London SW7 5BD (United Kingdom)

j.taylor@nhm.ac.uk

emilyglover@me.com

Submitted on 27 September 2017 | Accepted on 12 December 2017 | Published on 10 April 2018

urn:Isid:zoobank.org:pub:7652DEC7-3C6C-414F-AF2C-7C396D78F6F6

Taylor J. D. \&. Glover E. A. - Hanging on - lucinid bivalve survivors from the Paleocene and Eocene in the western Indian Ocean (Bivalvia: Lucinidae). Zoosystema 40 (7): 123-142. https://doi.org/10.5252/zoosystema2018v40a7. http://zoosystema.com/40/7

\section{ABSTRACT}

Rare species of three long-lived lucinid genera, Gibbolucina Cossmann, 1904, Barbierella Chavan, 1938 and Retrolucina n. gen., with origins in the Paleocene and Eocene of western Tethys, are present in the Mozambique Channel area of the southwestern Indian Ocean but absent elsewhere in the Indo-West Pacific. A new species, Gibbolucina zelee n. sp., is described from the Banc de la Zélée and western Madagascar that resembles Miocene species from western France. Since their origin in the Paleocene to the present day Barbierella species have always been rare. New records and images, including syntypes, are provided for Barbierella louisensis (Viader, 1951) from Mauritius and the Mozambique Channel, with Barbierella scitula Oliver \& Abou-Zeid, 1986 from the Red Sea regarded as synonym. A new genus, Retrolucina n. gen., is proposed with the living Lucina voorhoevei Deshayes, 1857 (usually called Eomiltha voorhoevei) as type species and also including Lucina defrancei Deshayes, 1857, a strikingly similar species from the Eocene of the Paris Basin. Retrolucina n. gen. differs from Eomiltha Cossmann, 1912 in shape, sculpture and hinge characters. Monitilora Iredale, 1930, another genus of Paleocene or earlier origins, includes a few living species in the Indo-West Pacific and is now identified from Mozambique with Monitilora sepes (Barnard, 1964) (formerly

KEY WORDS

Mollusca,

Mozambique Channel, new combination, new genus, new species.
Phacoides sepes Barnard, 1964). It is suggested that Gibbolucina, Barbierella and Retrolucina n. gen. species became isolated in the western Indian Ocean following the closure of the Tethyan Seaway in the early Miocene while their congeners in western Tethys became extinct. The survival of these rare genera, with restricted geographical ranges and seemingly small populations, runs counter to current ideas concerning long-term extinction risk. 


\begin{abstract}
RÉSUMÉ
Bivalves lucinidés du Paléocène et de l'Éocène survivant dans l'océan Indien occidental (Bivalvia: Lucinidae).

Des espèces rares appartenant à trois genres anciens de lucines, Gibbolucina Cossmann, 1904, Barbierella Chavan, 1938 et Retrolucina n. gen., dont l'origine se situe au Paléocène et à l'Éocène en Téthys occidentale, sont présentes dans la zone du Canal du Mozambique dans le sud-ouest de l'océan Indien, et absentes ailleurs dans l'Indo-Ouest Pacifique. Une nouvelle espèce, Gibbolucina zelee n. sp., est décrite du Banc de la Zélée et de l'ouest de Madagascar; elle ressemble à une espèce du Miocène de l'ouest de la France. Depuis leur origine au Paléocène jusqu'à nos jours, les espèces de Barbierella ont toujours été rares. Des signalisations nouvelles et des illustrations, dont celles de syntypes, sont données pour Barbierella louisensis (Viader, 1951) de l'île Maurice et du Canal du Mozambique, et Barbierella scitula Oliver \& Abou-Zeid, 1986 de la Mer Rouge est donnée comme synonyme. Le nouveau genre Retrolucina $\mathrm{n}$. gen. est établi avec pour espèce type l'espèce actuelle Lucina voorhoevei Deshayes, 1857 (habituellement appelée Eomiltha voorhoevei), et comprenant également Lucina defrancei Deshayes, 1857, une espèce de l'Éocène du Bassin Parisien qui lui est étonnamment semblable. Retrolucina n. gen. diffère d'Eomiltha Cossmann, 1912 par sa forme, sa sculpture et les caractères de sa charnière. Monitilora sepes (Barnard, 1964), du Mozambique (auparavant Phacoides sepes Barnard, 1964), est classée dans le genre Monitilora Iredale, 1930, un autre genre dont l'origine remonte au moins au Paléocène et qui comprend un petit nombre d'espèces actuelles de l'Indo-Ouest Pacifique. Les espèces de Gibbolucina, Barbierella et Retrolucina n. gen. ont pu se retrouver isolées dans l'Ouest de l'océan Indien à la suite de la fermeture de la Téthys au début du Miocène alors que leurs congénères de la Téthys occidentale se sont éteintes. La survie de ces genres rares, avec des aires de distribution restreintes et apparemment de petites populations, va à l'encontre des idées classiques sur les risques d'extinction à long terme.
\end{abstract}

\section{MOTS CLÉS \\ canal du combinaison nouvelle, espèce nouvelle, genre nouveau.}

\section{INTRODUCTION}

Marine bivalves of the family Lucinidae have attracted great interest following the discovery of their chemosymbiosis with sulphide-oxidising bacteria and many new species and genera have been described, particularly from the diverse central Indo-West Pacific region (Taylor \& Glover 2005, 2013; Glover \& Taylor 2007, 2016; Cosel \& Bouchet 2008). Although shallow water species from coral-reef habitats can be widely distributed across the tropical Indo-West Pacific, areas of endemism are also apparent. One such is the western Indian Ocean from the Red Sea to southern Africa including western Madagascar where several lucinid genera are recorded that do not occur further eastwards in the Indian Ocean. Remarkably, three of these genera Barbierella Chavan, 1938, Gibbolucina Cossmann, 1904 and Retrolucina n. gen. (described herein), first appeared in the early Cenozoic (Paleocene-Eocene of Europe c. 60-45 ma). Retrolucina voorhoevei (Deshayes, 1857) n. comb., previously placed in Eomiltha Cossmann, 1912 and recorded from Mozambique, has a striking shell morphology little resembling other living lucinids but is similar to an Eocene species 'Eomiltha' defrancei (Deshayes, 1857) from the Paris Basin. We propose a new generic name for the two species showing that $R$. voorhoevei $\mathrm{n}$. comb. differs considerably from the genotype of Eomiltha (Lucina contorta Defrance, 1825 from the Paleocene of France) although likely broadly related. Other unusual lucinids from the region include Rasta lamyi (Abrard, 1942) member of a genus otherwise known from a species from western Australia (Glover \& Taylor 1997;
Taylor et al. 2005) while Lucina roscoeorum (Kilburn, 1974) and Loripes clausus (Philippi, 1848) are the only representatives of the genera in the Indo-West Pacific. Also, Bourdotia Dall, 1901 first described from the early Eocene, survives off southern Oman as a single living species, B. boschorum Dekker \& Goud, 1994.

The antiquity of Barbierella, Gibbolucina and Retrolucina n. gen. and their survival in the western Indian Ocean is of interest because Barbierella species have always been rare and the other two genera uncommon or absent since the Eocene, with Barbierella and Gibbolucina last recorded during the Miocene and Retrolucina n. gen. not since the Eocene. The longevity of marine bivalve genera was analysed by Flessa \& Jablonski (1996) who showed that for IndoWest Pacific taxa the median ages were $8.6 \mathrm{ma}$ for the total sample and $14.7 \mathrm{ma}$ for those genera with a fossil record. The survival of these 'old' genera with restricted distributional ranges is also of interest in relation to extinction risk, with various studies of survivorship (Harnik 2011; Harnik et al. 2012; Finnegan et al. 2015; Orzechowski et al. 2015) concluding that marine genera with narrow geographic ranges and small population sizes are more vulnerable to extinction. Most records of these 'old' genera occur in the Mozambique Channel and on the eastern African coast. The separation of Madagascar from Africa to form the Mozambique Channel occurred in the early Cretaceous c. 120-130 ma (Rabinowitz et al. 1983; Rabinowitz \& Woods 2006) and its configuration has remained generally stable since that time. The channel is notable for complex 
eddy systems (Schouten et al. 2003; Sabarros et al. 2009) that likely result in larval retention and a possible resilience of communities and populations.

Recent collections from the Mozambique Channel (MNHN) have yielded new records of the rare lucinid genera as well as an undescribed living species of Gibbolucina that has enabled us to reassess the systematics of living species assigned to Barbierella, Gibbolucina and 'Eomiltha'. There is much taxonomic confusion regarding these genera: Eomiltha is often cited as a subgenus of Gibbolucina (e.g. Chavan 1969; Kilburn 1974) despite dissimilar shells and Gibbolucina species are often confused with Megaxinus Brugnone, 1880. From Mauritius, Lucina (Bellucina) louisensis Viader, 1951 is recognised as a species of Barbierella and the name predates B. scitula Oliver \& Abou-Zeid, 1986 previously regarded as the sole living species. Additionally, Monitilora Iredale, 1930, another Paleocene (or even earlier) genus, is recognised for the first time in the western Indian Ocean from Inhaca, Mozambique (previously described as Phacoides sepes Barnard, 1964). To clarify generic concepts we have studied type species of all the living and fossil genera and provide images and amended diagnoses.

\section{MATERIAL AND METHODS}

Lucinids from the Mozambique Channel were studied from MNHN collections made at Inhaca, Mozambique (Expédition INHACA 2011), NW Madagascar (Campagne MIRIKY 2009); southern Madagascar (Expédition ATIMO VATAE 2010) and from Banc de la Zélée (Expédition BENTHEDI 1977). Type specimens of described species were examined where available and images made. Comparative material of fossil and Recent lucinids, including the important Chavan collection (RBINS), were studied in various museum collections (listed below).

Dry but live-collected specimens of Gibbolucina zelee n. sp. were reconstituted using liquid detergent for gross anatomy and periostracal features. Scanning electron microscope images were made using a Quanta FEI 650 FEG instrument.

$\begin{array}{ll}\text { ABBREVIATIONS } \\ \text { H } & \text { shell height; } \\ \text { IWP } & \text { Indo-West Pacific Oceans; } \\ \text { L } & \text { shell length; } \\ \text { lv LV } & \text { left valve; } \\ \text { ma } & \text { million years; } \\ \text { PI } & \text { protoconch I length; } \\ \text { PII } & \text { protoconch II length; } \\ \text { pv } & \text { paired valves; } \\ \text { rv RV } & \text { right valve; } \\ \text { SEM } & \text { scanning electron microscopy; } \\ \text { stn } & \text { station; } \\ \text { T } & \text { tumidity single of valve; } \\ \text { v } & \text { valve. }\end{array}$

\section{Institutions}

AMS

ANSP
NHMUK Natural History Museum, London;

MNHN Muséum national d'Histoire naturelle, Paris;

MRSN $\quad$ Museo Regionale di Scienze Naturali, Turin;

NMW National Museum of Wales, Cardiff;

PRI Paleontological Research Institution, Ithaca, New York;

RBINS Royal Belgian Institute of Natural Sciences, Brussels;

SAM (CT) South African Museum, Capetown;

SM Sedgwick Museum of Earth Sciences, Cambridge;

USNM National Museum of Natural History, Washington DC.

\section{SYSTEMATICS}

Family LUCINIDAE Fleming, 1828

Subfamily LUCININAE Fleming, 1828

Genus Gibbolucina Cossmann, 1904

Phacoides (Gibbolucina) Cossmann in Cossmann \& Peyrot, 1904: 13.

TYPE SPECIES. - Venus callosa Lamarck, 1806: Eocene, Lutetian (original designation).

DiAGNOSIS. - Shell small L to $15 \mathrm{~mm}$, subtrigonal, ventrally rounded, umbones prominent. Shallow sulcus defining posterior dorsal area in most species. Lunule inset, long. Sculpture of irregular low commarginal lamellae. Hinge with two cardinal teeth in left valve and single, often bifid, cardinal in right valve, lateral teeth absent. Ligament short, in shallow resilifer. Anterior adductor muscle scar short, narrow, detached for half to $2 / 3$ of length, pallial line entire, inner shell margin smooth, interior often thickened, with pallial blood vessel scar in deep groove.

Geological Range. - Eocene (Lutetian) to Recent. The fossil record of Gibbolucina species extends from the early Eocene to the Miocene.

INCLUDED SPECIES. - Eocene. Lutetian: Gibbolucina callosa (Lamarck, 1806) (Fig. 1A-G) and G. gibbosula (Lamarck, 1806).

Bartonian. Gibbolucina lefevrei (Cossmann, 1887) (Fig. 1J, K), G. axinoides (Dufour, 1881) (Fig. 1H, I), G. profunda (Dufour, 1881). Priabonian (Ludien). Gibbolucina incomposita (von Koenen, 1893) see Pacaud \& Ledon 2007).

Miocene Aquitanian. Gibbolucina avitensis (Cossmann \& Peyrot, 1912)(1912: 271-273, pl. 27, figs 14-17). Saint Avit, Landes, Aquitaine (MNHN.F.06430).

Burdigalian. Gibbolucina trigonula (Deshayes, 1830) Moulin de Gamachot, Aquitaine (Cossmann \& Peyrot 1912: pl. 26, figs 7073) (Fig. 1L-P).

Pliocene. A Late Pliocene-early Pleistocene species, Gibbolucina salebrosa (Woods, 1931), was described from southwestern Australia (see Ludbrook 1978: pl. 3, figs 6-9) but this lacks hinge teeth, and the deeply scooped lunule of Gibbolucina and also has widely spaced prominent commarginal lamellae. We regard this species as distinct from Gibbolucina but in a broadly related genus (undescribed). Another Pliocene species, Gibbolucina confirmans (Ludbrook, 1955), was described from two incomplete shells from a borehole near Adelaide, South Australia but the generic assignment is doubtful. Recent. Gibbolucina zelee n. sp.

\section{COMPARISON WITH OTHER GENERA}

Despite Chavan (1969) and others including Eomiltha as a subgenus of Gibbolucina or, alternatively, Gibbolucina as a subgenus of Eomiltha (Ludbrook 1955), there is little similarity of shell characters (see below) and any relation- 


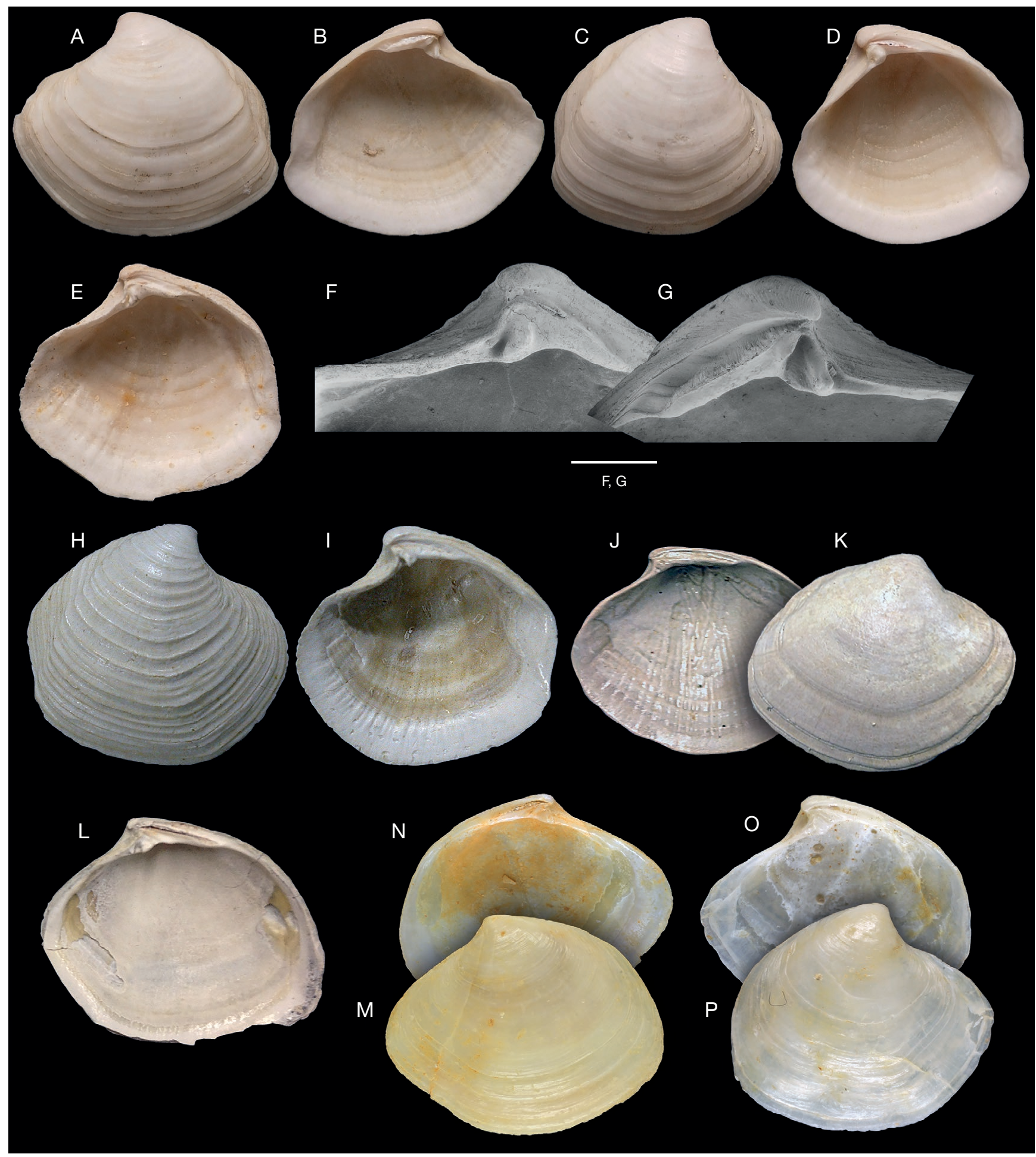

FIG. 1. - Gibbolucina Cossmann, 1904 fossil species: A-G, Gibbolucina callosa (Lamarck, 1806), Eocene, Lutetian, Calcaire Grossier, Grignon, France, NHMUK Earth Science L 14106; A, B, exterior and interior of left valve, $L 11.7 \mathrm{~mm}$; C, D, exterior and interior of right valve, $L 10.3 \mathrm{~mm}$; E, interior of right valve, L $11.2 \mathrm{~mm}$; F, G, detail of hinge teeth of right (E) and left (B) valves; $\mathbf{H}, \mathbf{I}$, Gibbolucina axinoides (Dufour, 1881) exterior and interior of right valve, Eocene, Bartonian, Saint-Aignan-Grandlieu, Pierre-Aiguë, Loire-Atlantique, France, (MNHN.F.R53986), L 12 mm; J, K, Gibbolucina lefevrei (Cossmann, 1887) interior and exterior of right valve, Eocene, Bartonian, Bezu le Guery, France (MNHN), L 25 mm; L, Gibbolucina trigonula (Deshayes, 1830) interior of right valve, Miocene, Aquitanian, Villandraut, Gironde, France (MNHN), L 22 mm; M, N, Gibbolucina trigonula (Deshayes, 1830) Miocene, Burdigalian, Corbleu (Moulin de Carro), Landes, France. Images Pierre Lozouet, L $31 \mathrm{~mm}$; O, P, Gibbolucina cf trigonula interior and exterior of right valve, locality as M, L 10 mm. Scale bar: F, G, $1.0 \mathrm{~mm}$. 
ship is highly unlikely. In contrast, several described genera have similar characters to Gibbolucina and are likely broadly related. These are Megaxinus (type species Lucina transversa Bronn, 1831), Rasta Taylor \& Glover, 2000 (type species Rastafaria thiophila Taylor \& Glover, 1997 [Taylor \& Glover 1997, 2000]), and Parvidontia Glover \& Taylor, 2007 (type species P. laevis Glover \& Taylor, 2007). To date, only Rasta lamyi has been included in molecular analyses (Taylor $e t$ al. 2011, 2016) where it groups in the subfamily Lucininae.

Megaxinus species are often similar in shape to Gibbolucina but all lack hinge teeth, although there are sometimes irregular folds on the hinge plate. They also exhibit ontogenetic changes in shape, becoming relatively higher and thicker shelled with age (Glover \& Taylor 1997; Cosel \& Bouchet 2008). Furthermore, the anterior adductor muscle scar is longer and detached from pallial line for about $2 / 3$ of length rather than about half of length in most Gibbolucina species. Rasta species also similarly lack hinge teeth but have a subtrigonal shape, higher than long, with prominent umbones and the two known species, $R$. thiophila and $R$. lamyi, possess in live or fresh shells, distinctive, long periostracal extensions (Glover \& Taylor 1997; Taylor \& Glover 1997; Taylor et al. 2005). An earlier Rasta-like species is Megaxinus ellipticus var. trigona Sacco, 1901 described from the early Pliocene of northern Italy (MRSN BS154.02.006) and which has a similar higher than long shape, with sharp, curved umbones.

Another similar genus, Parvidontia, was introduced (Glover \& Taylor 2007) based on P. laevis from New Caledonia, a small species with sub-circular, thin shells and small cardinal teeth. Subsequently, Glover \& Taylor (2016) concluded that the $P$. laevis specimens were likely juvenile shells and described a second species, $P$. mutabilis Glover \& Taylor, 2016, from the Philippines that, in larger individuals, has the general shell form of Megaxinus but with small cardinal teeth. Parvidontia is similar to Gibbolucina in shape but has a very thin hinge plate, a sculpture of fine commarginal lamellae and lacks a thick periostracum.

Gibbolucina zelee n. sp. (Fig. 2A-S)

\section{urn:Isid:zoobank.org:act:3994D94E-2522-4608-B837-513901FE615B}

TYPe MATERIAL. - Holotype. Whole shell, L 15.3 mm, H 14.8 mm, T single valve $4.3 \mathrm{~mm}$ (MNHN-IM-2000-33710). Shell in 70\% ethanol rehydrated from dried sample.

Paratypes. From type locality, MNHN-IM-2000-33711 figured 1 whole shell with body rehydrated (Fig. 2E-G) L $12.7 \mathrm{~mm}$, H $12.5 \mathrm{~mm}$; 1 dry shell L $17.7 \mathrm{~mm}, \mathrm{H} 16.2 \mathrm{~mm}$; 2 whole shells, L $10.5 \mathrm{~mm}$, H $10.7 \mathrm{~mm}$, L $9.2 \mathrm{~mm}, \mathrm{H} 9.3 \mathrm{~mm}$; unfigured 2 whole shells with bodies reconstituted, L $16.9 \mathrm{~mm}, \mathrm{H} 17.4 \mathrm{~mm}$, (NHMUK paratype 20170401), L $13.7 \mathrm{~mm}, \mathrm{H} 13.8 \mathrm{~mm}$; unfigured 6 whole shells and 3 single valves.

Type Locality. - Mozambique Channel, Banc de la Zélée, Expédition BENTHEDI 1977 stn R110, 12²5'6”S, 4616'2”E, $24 \mathrm{~m}$, 10.IV.1977. Shallow, sandy bottom in the lagoon with dense seagrass beds of Thalassodendron ciliatum (Thomassin et al. 2009).
ETymology. - From French for zealous, named for Banc de la Zélée itself named after one of the ships of J. Dumont d'Urville's Astrolabe Expedition (1837-1840).

OTHER MATERIAL EXAMINED. - Madagascar. Campagne MIRIKY,

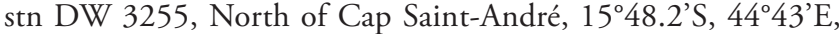
36-39 m, 1 rv (L $15.3 \mathrm{~mm}$ ) (MNHN). Campagne MIRIKY, stn CP3287, in front of Baie Narendry, $1^{\circ} 33.7^{\prime} \mathrm{S}, 47^{\circ} 27.9^{\prime} \mathrm{E}$, 48-54 m, 1 rv (L $14.6 \mathrm{~mm}$ ) (MNHN). Toliara, Grand Récif de Tuléar, Andeteky area, outer reef slope, lower platform $24 \mathrm{~m}$ sand, Thomassin stn TUL 222, $2 \mathrm{lv}$ (1 broken, and L $4.3 \mathrm{~mm}$ ), 1 rv (L $10.9 \mathrm{~mm}$ ) (MNHN). Beloza, Grand Récif de Tuléar lagoon, inner coral reef, coarse sand $<1 \mathrm{~m}$, Thomassin stn TUL 257, $1 \mathrm{lv}$ (L $11.1 \mathrm{~mm})$ (MNHN). South (2-3 mi) of Nosy Iranja, $31 \mathrm{mi}$ $(50 \mathrm{~km}) \mathrm{SW}$ of Nossi Bé, 15-18 fthms (27-33 m), muddy sand, stn H, 12 v (ANSP 263071). West (7 mi) of Angorombalo, SW Nossi Bé, $35 \mathrm{fthms}$ (64 m), fine sand and mud, stn H66, $12 \mathrm{v}$ juveniles (ANSP 261566). West (4 mi) of Nosy N'Tangam, SW Nossi Bé, $20 \mathrm{fthms}(37 \mathrm{~m})$, muddy sand, stn H 68, I rv, (L $13.7 \mathrm{~mm}$ ) (ANSP 260083).

Distribution. — Mozambique Channel, Western Madagascar.

\section{DESCRIPTION}

Shell small, longer than high, L to $17.7 \mathrm{~mm}, \mathrm{H}$. to $16.0 \mathrm{~mm}$, subtrigonal, anteriorly extended, umbones prominent. Thin, lightweight, glossy or waxy shell with thick periostracum; in a rehydrated specimen this is clear, flexible with pleated flaps (Fig. 2E). Ventral edge of periostracum extending beyond the shell margin (Fig. 2G). In dry specimens, periostracum thick and encrusting. Sculpture of irregular, widely spaced, low, commarginal lamellae. Shell often with growth distorsions (Fig. 2H). Protoconch: P1 + P2 $=210 \mu \mathrm{m}$, PI $189 \mu \mathrm{m}$, with PII a narrow rim with no growth increments (Fig. 2S). Lunule ovate, scooped, symmetrical. Ligament short, set on shallow resilifer. Hinge teeth: LV with two, small, cardinal teeth, RV with a single bifid cardinal. Lateral teeth absent. Anterior adductor muscle scar medium long, detached for $1 / 2$ of length at an angle of $15^{\circ}$. Posterior scar small, elongate, ovoid. Pallial line entire. Ventral margin smooth, shell interior often thickened particularly across the posterior and around the anterior adductor scar.

\section{Anatomy}

Limited observations from a rehydrated body (Fig. 2G) show ctenidia with single thickened demibranchs occupying half of mantle cavity, a vermiform foot, simple posterior apertures lacking papillae and short ventral mantle fusion.

\section{REMARKS}

Gibbolucina zelee n. sp. is similar in shape and hinge characters to Gibbolucina trigonula from the Miocene of the Aquitaine Basin, France (Fig. 1O, P). The only other similar species in the Indian Ocean is Megaxinus arabicus Glover \& Taylor, 1997 (holotype NMW. Z.1995.009) described from a depth of $58 \mathrm{~m}$ off southern Oman. Although this has the overall shape of Gibbolucina species, the hinge has no defined teeth only some irregular folds and the anterior adductor scar is longer, both features similar to Megaxinus transversus (Bronn, 1831). 


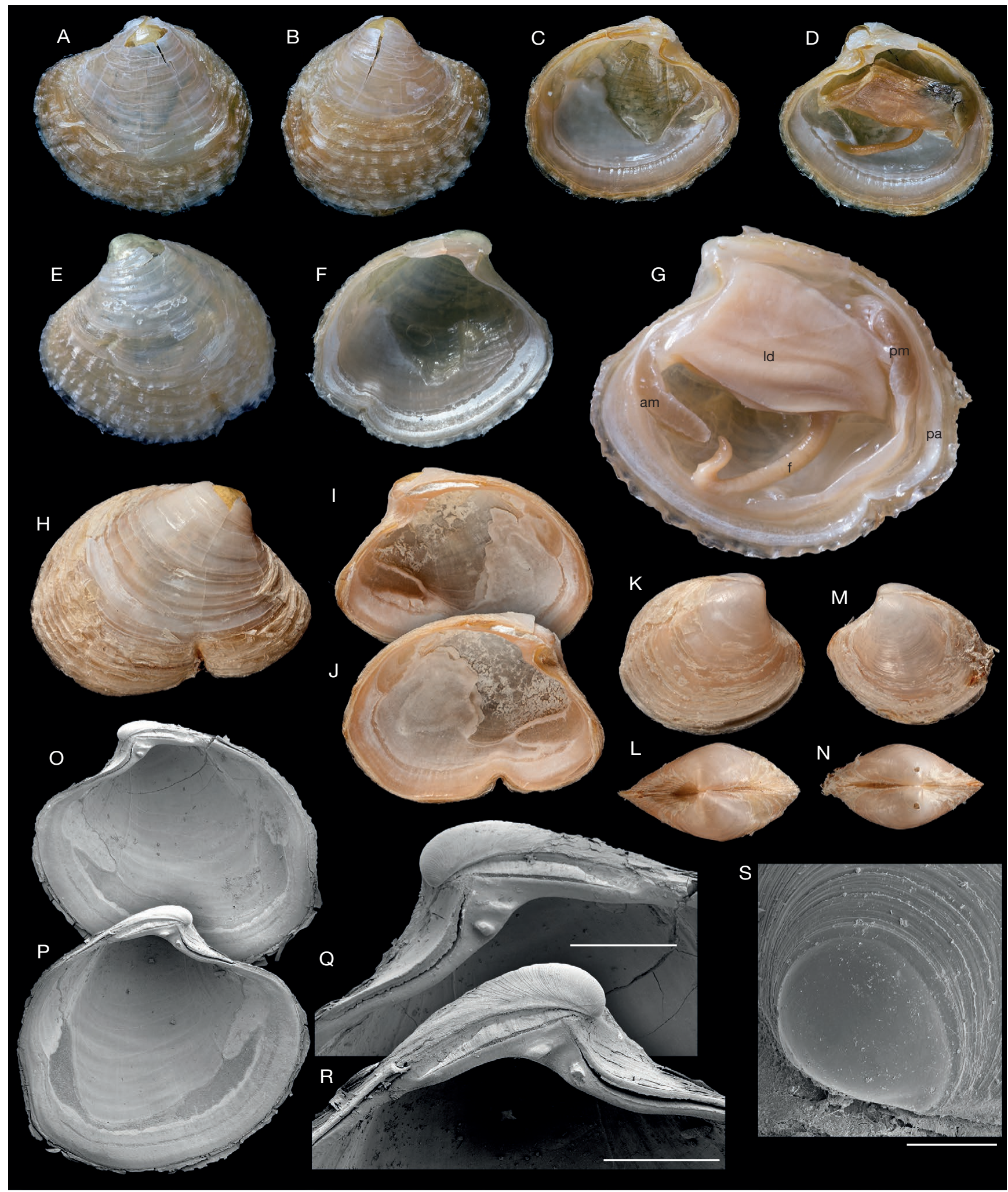

FIG. 2. - Gibbolucina zelee n. sp., Banc de la Zélée, Mozambique Channel, BENTHEDI stn R110, 24 m: A-D, holotype (MNHN-IM-2000-33710) exterior and interior of left and right valves, L $15.3 \mathrm{~mm}$; E, F, paratype (MNHN-IM-2000-33711) exterior and interior of left valve, L $12.7 \mathrm{~mm}$; G, paratype (as E, F) interior of right valve with reconstituted body, L $12.7 \mathrm{~mm}$; H-J, paratype (MNHN-IM-2000-33711) exterior of right valve and interior of right and left valves, $L 17.7 \mathrm{~mm}$; K, L, paratype (MNHN-IM-2000-33711) exterior of right valve and dorsal view, L $10.5 \mathrm{~mm} ; \mathbf{M}, \mathbf{N}$, paratype (MNHN-IM-2000-33711) exterior of left valve and dorsal view, L $9.2 \mathrm{~mm}$; O, P, paratype (MNHN-IM-2000-33711) interior of right and left valves, L $8.9 \mathrm{~mm}$; Q, R, paratype (MNHN-IM-2000-33711) detail of hinge teeth of right and left valves of $\mathbf{O} \& \mathbf{P}$; $\mathbf{S}$, protoconch of $\mathbf{Q}$. Abbreviations: am, anterior adductor muscle; $\mathbf{f}$, foot; Id, left demibranch; pa, posterior apertures; $\mathbf{p m}$, posterior adductor muscle. Scale bars: Q, R, $1.0 \mathrm{~mm} ; \mathrm{S}, 100 \mu \mathrm{m}$. 


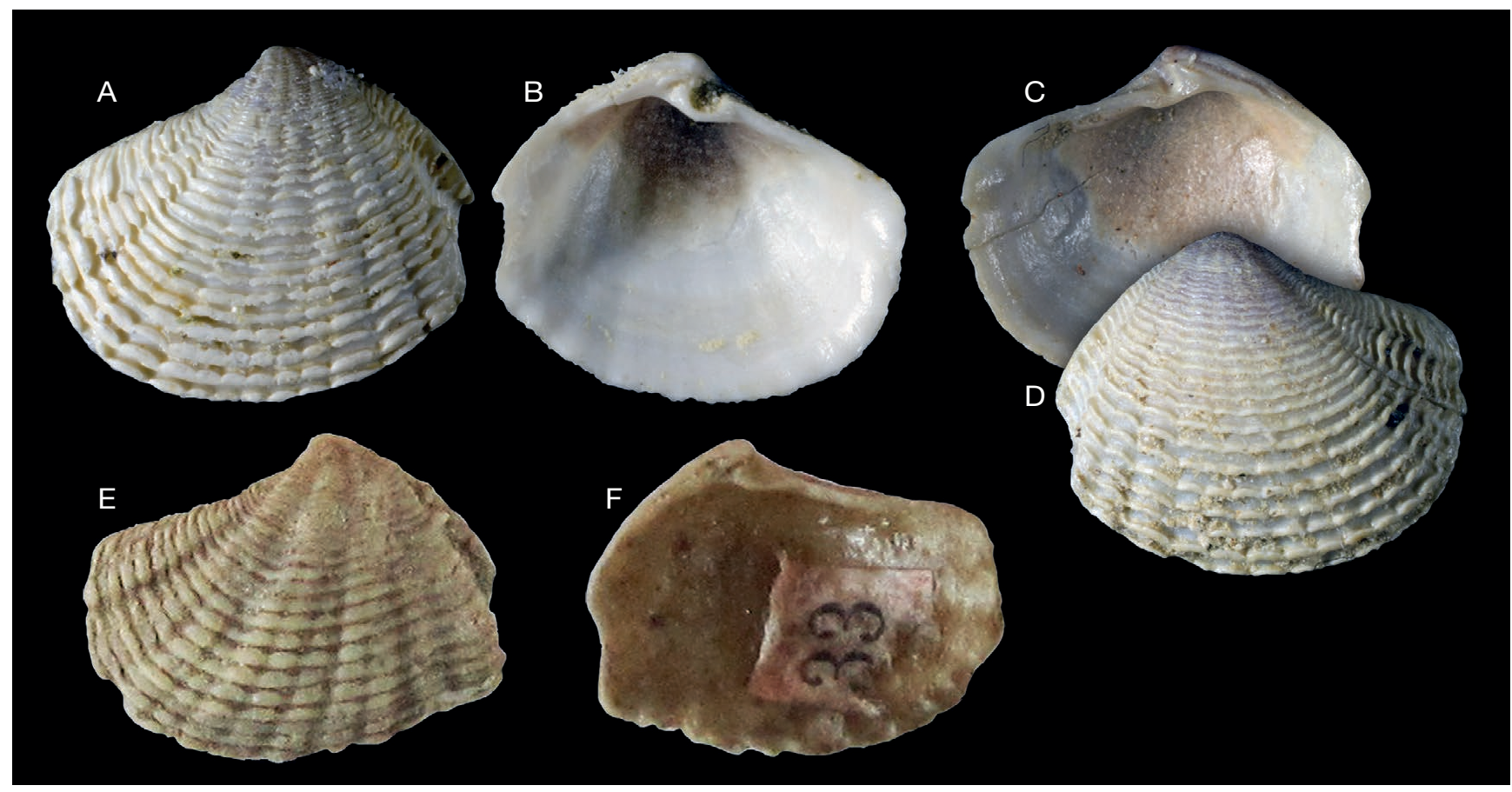

FIG. 3. - Barbierella Chavan, 1938 fossil species: A-D, Barbierella barbieri (Deshayes, 1857) Eocene, Lutetian, Parnes, Oise, France; A, B, exterior and interior of left valve (MNHN.F.A52519 coll. Pacaud), L 6.3 mm; C, D, exterior and interior of right valve (MNHN.F.A52520 coll. Pacaud), L 7.2 mm. Images by Peter Massicard (MNHN); E, F, Barbierella miobarbieri (Sacco, 1901) holotype of Here miobarbieri Sacco, 1901. Exterior and interior of the single right valve, Museo di Geologia e Paleontologia della Universita di Torino BS, 154.09.001, Miocene, Elveziano (Langhian?), Bersano, Italy, L 17 mm. Images by Daniele Ormezano (MRSN).

\section{Genus Barbierella Chavan, 1938}

\section{Cavilucina (Barbierella) Chavan, 1938: 115.}

Type species. - Lucina barbieri Deshayes, 1857, early Eocene, Paris Basin (original designation).

DiAGNOSIS. - Small, less than $12 \mathrm{~mm}$ long, ovately trigonal, prominent posterior sulcus, with marginal sinus. Sculpture of prominent, reflexed, regularly spaced, scalloped, commarginal lamellae with underlying radial undulations. Thickening of lamellae aligned in radial lines. Lamellae raised into short spines along ventral edge of posterior sulcus. Lunule short, deeply impressed. Ligament short, external. Hinge: RV with a single narrow cardinal tooth, LV with a socket. Lateral teeth absent or vestigial, small anterior lateral tooth present in B. barbieri. Anterior adductor muscle scar short, diverging from pallial line for about $1 / 3$ of length. Pallial line entire. Inner shell margin undulose to coarsely plicate.

Geological RAnge. - Paleocene (Late Danian) to Recent.

INCLUDED SPECIES. - Paleocene. Late Danian: Barbierella briarti (Cossmann, 1908) Calcaire de Mons, Belgium (see Glibert \& van de Poel 1973: 28, pl. 5, fig. 5).

Eocene. Barbierella barbieri (Deshayes, 1857)(1857: 651-652, pl. 43, figs 1-5) known from Ypresian and Lutetian of the Paris Basin, France (Fig. 3A-D); also figured by Cossmann \& Pissarro (1904-6, pl. 24, fig. 82-16). Barbierella navicula (Cossmann, 1904) (1904: 152, pl. 10, figs 18-20) is a similar species from Bartonian sands at Bois-Gouët, Loire-Atlantique, France.

Miocene. Barbierella miobarbieri (Sacco, 1901)(1901: 97, pl. 21, fig. 6), Piedmont, Italy (Fig. 3E, F), see also Merlino (2007: pl. 15, fig. 12a, b). Recent. Barbierella louisensis (Viader, 1951) Mauritius and Mozambique Channel (Fig. 4) and synonym B. scitula Oliver \& Abou-Zeid, 1986, northern Red Sea (Fig. 4E-G).

\section{REMARKS}

The hinge of B. barbieri was illustrated by Cossmann (1913: 86, fig. 100) who claimed two cardinal teeth in each valve with the anterior much reduced. He also illustrated anterior and indistinct posterior lateral teeth in each valve but these are barely visible in Eocene specimens we have examined (Fig. 3B, C). In living $B$. louisensis the lateral teeth are absent and there are no visible cardinal teeth in the left valve but they may be fused with the edge of the lunule and ligamental ridge.

Prior to the introduction of the name Barbierella the placement of Lucina barbieri had been unstable and variously included in Phacoides Agassiz, 1846, Here Gabb, 1866 and Lucinisca Dall, 1901, although Cossmann (1913: 86) recognised its unusual features and uncertain assignment. Proposing Barbierella as a subgenus Chavan (1938: 114-115) considered it related to but separate from Cavilucina P. Fischer, 1887 and also noted a possible resemblance to Recurvella Chavan, 1937 (type species Lucina dolabra Conrad, 1833) from the Eocene of eastern United States of America (USA). Sacco (1901) placed B. miobarbieri in Here Gabb, 1866, Recent, northeastern Pacific, probably because of the deeply scooped lunule but otherwise the shells are dissimilar. Later, Woodring (1925: 121) stated "The lucinoid described by Sacco as Here miobarbieri from the Helvetian of the Piedmont basin, probably is a Pleurolucina". However, although there is some similarity of external sculpture the hinge teeth are quite different, Pleurolucina Dall, 1901 having two cardinal teeth and prominent lateral teeth in each valve. The deeply scooped lunule impinging on the cardinal teeth and commarginal lamellae resemble some living 
Lamellolucina Taylor \& Glover, 2002 species such as L. gemma (Reeve, 1850) but all species in the genus have strong lateral teeth. Although from shell characters we place Barbierella in the Lucininae the relationships of this enigmatic genus remain uncertain pending inclusion in molecular analyses.

Throughout their geological range Barbierella species have always been rare. In the original description of $B$. barbieri Deshayes (1857: 652) remarked on "this rare and beautiful shell". Sacco (1901: 97) said that B. miobarbieri (as Here) was rather rare in the Miocene of northern Italy. From probable mid-late Miocene rocks of Cyprus, Reed (1935: 5) recorded a partial external mold (SM C8911) of Barbierella miobarbieri (as Phacoides (Pleurolucina)) and Studencka et al. (1998) recorded B. miobarbieri as rare in mid-Miocene deposits of Parathethys.

\section{Barbierella louisensis (Viader, 1951)} (Fig. 4A-W)

Lucina (Bellucina) louisensis Viader, 1951: 133, pl. 3, fig. 6.

Barbierella scitula Oliver \& Abou-Zeid, 1986: 222, pl. 23, figs 1-4.

Barbierella louisensis - Huber 2015: 430.

Type MATERIAL. - Lucina (Bellucina) louisensis: 3 syntypes (Viader mentioned 5 valves), single left valves, L $6.2 \mathrm{~mm}$, H $5.2 \mathrm{~mm}$; L $5.5 \mathrm{~mm}, \mathrm{H} 4.7 \mathrm{~mm}$ (Viader figured shell); broken valve H $5.4 \mathrm{~mm}$ (AMS C 305545). Barbierella scitula: holotype, off Ras Budran, Gulf of Suez, Red Sea, $30 \mathrm{~m}$, L $8.2 \mathrm{~mm}$, H $7.4 \mathrm{~mm}$ (NMW Z 1982.68.1). Paratypes: (NMW.Z. 1986.11.1), L 9.4 mm, H 8.7 mm; (NHMUK 1986030), L 8.7 mm, H 7.7 mm.

Type LOCAlity. — Off Port Louis, Mauritius.

OTHER MATERIAL EXAMINED. - Northern Mozambique Channel: Banc de la Zélée, Expédition BENTHEDI, stn R110, lagoon with sandy bottom and dense seagrass Thalassodendron ciliatum. $12^{\circ} 25^{\prime} 6 \mathrm{~S}$, $46^{\circ} 16^{\prime} 2$ E, $24 \mathrm{~m}, 10 . \mathrm{IV} .1977,1 \mathrm{pv}$, co-occurs with Gibbolucina zelee n. sp. (MNHN). Mozambique: Inhaca Island, "Nord de la

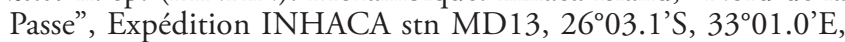
50-53 m, 30.XI.2011, 9 v (MNHN).

Distribution. - Northern Red Sea, Mozambique Channel, Mozambique, Mauritius, Réunion.

\section{DESCRIPTION}

Small, L to $9.4 \mathrm{~mm}, \mathrm{H}$ to $8.7 \mathrm{~mm}$, longer than high. Anteriorly extended, anteriorly rounded but posteriorly truncate, anterior dorsal margin long. Umbones prominent. Sculpture of prominent, dorsally recurved, nodulose, commarginal lamellae with narrow, deep interspaces. Lobate nodules on lamellae aligned to give appearance of radial ribbing. Posterior sulcus with lower, sharper lamellae and forming a curved marginal sinus. Shallow anterior sulci present. Anterior and posterior margins of posterior sulcus with some lamellae projected into blunt spines. Microsculpture finely punctate. Protoconch (Inhaca specimen) (Fig. 4W): PI + PII $=190 \mu \mathrm{m}, \mathrm{PI}=172 \mu \mathrm{m}$ smooth, PII a narrow rim. Lunule short, deeply scooped, smooth. Ligament short, in shallow groove. Hinge teeth: right valve with single cardinal tooth, left valve with central socket, anterior cardinal possibly fused with edge of lunule; lateral teeth absent. Anterior adductor muscle scar short, detached for about $1 / 3$ of length, posterior scar ovate. Pallial line entire. Inner shell margin coarsely dentate. Colour white.

\section{REMARKS}

This is a rare species in the western Indian Ocean and Red Sea. Despite intensive sampling (Zuschin \& Oliver 2003) there have been no other Red Sea records except that of Oliver \& Abou-Zeid (1986). Around Mauritius, the species has not been recorded since Viader's (1951) original description nor from intensive sampling around southern Madagascar (ATIMO VATAE Expédition MNHN 2010). The shell from Réunion illustrated as $B$. louisensis (http://vieoceane.free.fr) is a species of Notomyrtea Iredale, 1924 but the Barbierella sp. is B. louisensis. Major features of the anatomy of B. scitula were described and illustrated by Oliver \& Abou-Zeid (1986). These features are common to most lucinids and include ctenidia with single demibranchs, vermiform foot, short length of posterior mantle fusion, the inhalant aperture fringed with papillae and the exhalant introvert 'siphon'.

\section{Subfamily MilthinaE Chavan, 1969}

\section{REMARKS}

Most of the genera with living species included in the subfamily by Chavan (1969) have now been assigned to other subfamilies (Taylor et al. 2011). Two genera, Miltha H. \& A. Adams, 1853 and Eomiltha Cossmann, 1912, remain and the status of the subfamily is unresolved pending inclusion of any of the three living species in molecular analysis. Despite the name, shell characters of Eomiltha have little similarity to Miltha and any relationship is doubtful. In the following section we introduce a new genus name for the living species usually called Eomiltha voorhoevei together with an antecedent species from the Eocene. To provide background to this decision we briefly review Eomiltha below.

\section{Genus Eomiltha Cossmann, 1912}

Eomiltha Cossmann in Cossmann \& Peyrot, 1912: 269.

TYPE SPECIES. - Lucina contorta Defrance, 1825, Paleocene, Thanetian, Abbecourt, France (original designation).

DiAGNOSIS. — Slender, flat shelled, ovoid, anteriorly rounded, posteriorly truncate with shallow sulcus. Sculpture of low commarginal lamellae, fine radial threads. Two cardinal teeth in each valve, lateral teeth absent. Anterior adductor muscle scar, long, narrow, arcuate with posterior termination beyond mid point of shell. Pallial line with sharp angle posteriorly to adductor scar (Fig. 7E, F). Inner shell margin smooth.

\section{Geological RANGE. - Paleocene (Danian) to ?Miocene}

INCLUDED SPECIES - Paleocene. Late Danian: Eomiltha alburgensis (Vincent, 1930), Calcaire de Mons, Belgium RBINS I.G. 6496 (Fig. 5A). Thanetian: Eomiltha contorta (Defrance, 1825) (1825: 99-100, pl. 16, figs 1, 2). Abbecourt, Paris Basin (Figs 5B-G; 7E, F). 


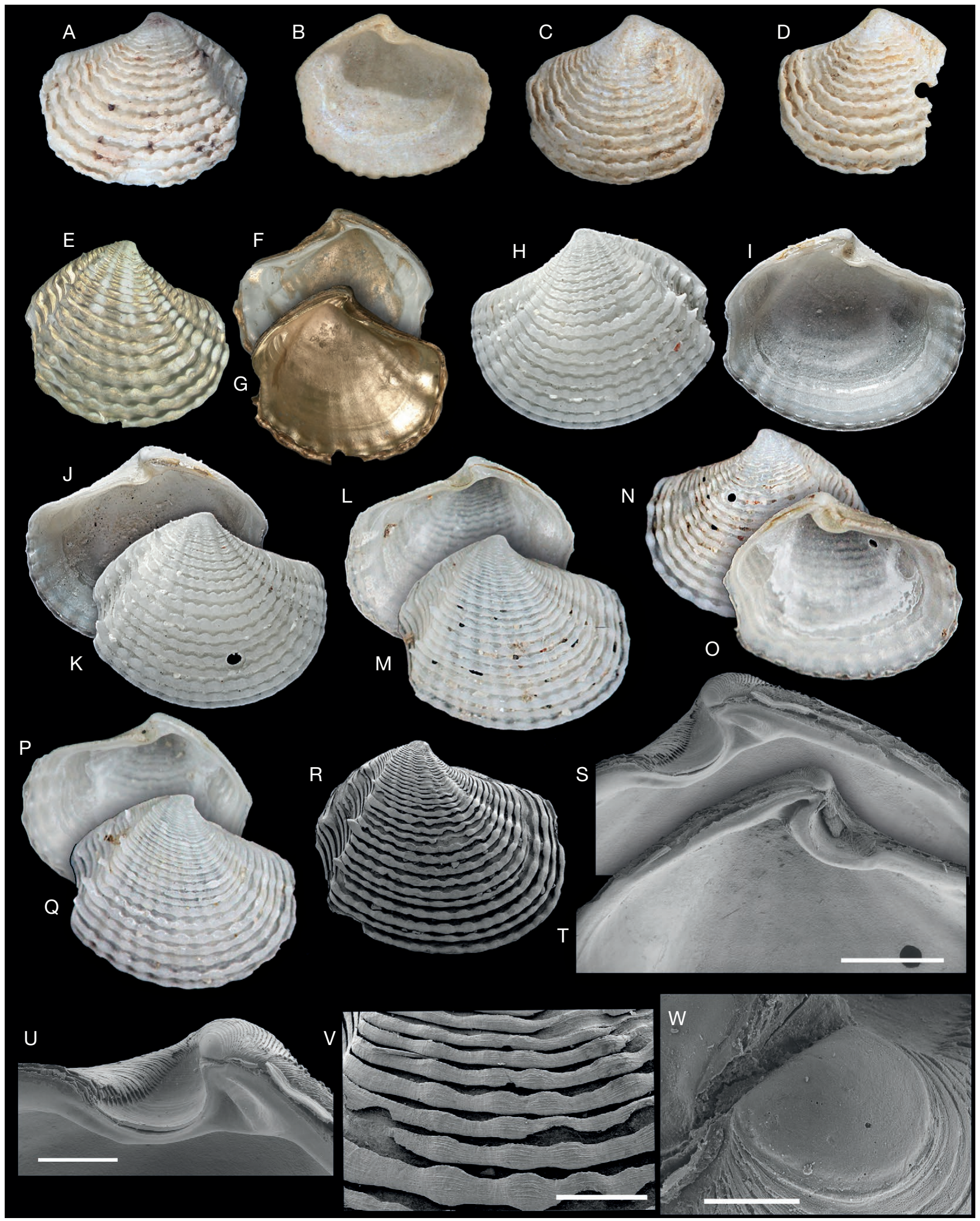

FIG. 4. - Barbierella louisensis (Viader, 1951): A-D, Lucina (Bellucina) louisensis Viader, 1951 syntypes (AMS C.305545), off Port Louis, Mauritius, L (A, B) 6.2 mm, (C) $5.5 \mathrm{~mm}, \mathrm{H}$ (D) $5.4 \mathrm{~mm}$. Images by A. C. Miller, Copyright: Australian Museum; E-G, Barbierella scitula Oliver \& Abou-Zeid, 1986, holotype (NMW.Z.1982.68.1) exterior of right and interior of right and left valves (gold coated for SEM), off Ras Budran, Gulf of Suez, Red Sea, $30 \mathrm{~m}$, L $8.2 \mathrm{~mm}$, Images copyright NMW; H-K, Barbierella louisensis, Banc de la Zélée, Mozambique Channel, BENTHEDI stn 110, $24 \mathrm{~m} ; \mathbf{H}, \mathbf{I}$, exterior and interior of left valve, L $7.8 \mathrm{~mm} ; \mathbf{J}, \mathbf{K}$, interior and exterior of right valve, L $7.8 \mathrm{~mm}$; L-W, Barbierella louisensis Inhaca, Mozambique, INHACA stn MD13, 50-53 m (MNHN); L, M, interior and exterior of right valve, L $6.0 \mathrm{~mm} ; \mathbf{N}, \mathbf{O}$, exterior and interior of left valve, L $5.9 \mathrm{~mm} ; \mathbf{P}, \mathbf{Q}$, interior and exterior of right valve, L $5.9 \mathrm{~mm}$; R, exterior of right valve coated SEM image, $\mathrm{L} 6.5 \mathrm{~mm} ; \mathbf{S}, \mathbf{T}$, detail of hinge area of right and left valves; $\mathbf{U}$, detail of lunule and dentition of right valve; $\mathbf{V}$, detail of sculpture of $\mathbf{R}, ; \mathbf{W}$, protoconch. Scale bars, S, T, 1 mm; U, V, $500 \mu \mathrm{m} ; \mathrm{W}, 100 \mu \mathrm{m}$. 
Eocene. Ypresian: Eomiltha contortula (Deshayes, 1857) (1857: pl. 40, figs 19-22), Cossmann \& Pissarro (1904-1906: pl. 24, fig. 82-9), Paris Basin.

Eomiltha pandata (Conrad, 1833), Middle Eocene, Claiborne Group, Alabama, USA (Figs 5H, I; 7G). See Bretsky (1976: 290291, pl. 33, figs 4-7).

Miocene. Eomiltha scolaroi Vokes, 1969, early-mid Miocene Chipola Formation (Fig. 5J, K), is similar in shape to Eomiltha pandata. Eomiltha xustris (Gardner, 1926), Early Miocene, Alum Bluff, Florida. Although claimed as an Eomiltha species by Vokes (1969b) Phacoides (Miltha) xustris Gardner, 1926 (holotype USNM 352496) has the shape and adductor musculature more similar to Miltha.

\section{REMARKS}

Fossils identified as Eomiltha are known from deposits in the eastern USA (Vokes 1969b; Bretsky 1976). These are Eomiltha pandata (Conrad, 1833) from the mid-Eocene, Claiborne Group, Alabama (Figs 5H, I; 7G) and E. scolaroi Vokes, 1969 from the early-mid Miocene Chipola Formation of Florida (Fig. 5J, K). The two species are similar to each other and have a subcircular, discoidal shape rather than the elongate shape of Retrolucina n. gen. or Eomiltha with distinct lines of secondary pallial attachment scars located within the pallial line and extending from the anterior to posterior. Eomiltha pandata has a widely bifid posterior cardinal tooth in the right valve. These north American species probably represent a distinct clade from the European lineages and separable at generic level.

Chavan (1938: 98) suggested placement in Eomiltha of 'Miltha' callipteryx (Tournouer, 1874) figured by Cossmann \& Peyrot (1912: pl. 27, figs 18-21) from the Miocene of Aquitaine, France. This has distinctive widely spaced commarginal lamellae and in shape is similar to Eomiltha species but has a much shorter anterior adductor scar and is very similar in shape and sculpture to the living Falsolucinoma leloeuff Cosel, 2006 from West Africa. The latter species is now placed using molecular data near to Lucina in the Lucininae (our unpublished data). Another putative Eomiltha species that can be discounted is Miltha (Eomiltha) multilamellata (Deshayes, 1830) described and figured by Cossmann \& Peyrot (1912: pl. 27, figs 3-7) from the Miocene of Aquitaine, but this has the characters of Armimiltha Olsson \& Harbison, 1953) (type species Lucina disciformis Heilprin, 1886 from Plio-Pleistocene of Florida). Phacoides (Miltha) woodi Olsson, 1930 from the Eocene of Peru was referred to Eomiltha by Vokes (1969b: 113) but the syntype (PRI 24173) has characters of Miltha. Moore (1988) refers two species from the Paleocene and Eocene of California to Eomiltha; of these Gibbolucina (Eomiltha) packi (Dickerson 1916) is most likely a Miltha species (see Vokes 1939, 1969a) and G. (Eomiltha) gyrata (Gabb, 1864) is a compressed shell of uncertain placement.

In Eocene faunas there were several lucinid genera similar to Eomiltha in possession of long, narrow anterior adductor muscle scars extending to around the mid-line of the shells. A number of species lacking hinge teeth have been assigned to Pseudomiltha (type species Lucina gigantea Deshayes, 1825) but there is considerable morphological disparity among the species (e.g. P. mutabilis (Lamarck, 1807) suggesting probable different clades. Another form with a long anterior adductor scar is the largest known lucinid, Superlucina megameris (Dall, 1901), described from the Eocene of Jamaica (Taylor \& Glover 2009), but previously placed in Eomiltha. Lucinids with very long, thin, anterior adductor muscles are absent from modern faunas except for Retrolucina voorhoevei n. comb.

There is much confusion concerning the relationships of Eomiltha: it has been placed as a subgenus of Gibbolucina (e.g. Chavan 1938, 1969; Kilburn 1974) but there is little similarity of shells. Alternatively, it has been classified as subgenus of Miltha (e.g. Bretsky 1976) but the shells differ in shape and musculature.

\section{Genus Retrolucina n. gen.}

\section{urn:Isid:zoobank.org:act:DAFC3EBA-0C19-4D63-8248-65A6F761670A}

TYPE SPECIES. - Lucina voorhoevei Deshayes, 1857. Recent, Western Indian Ocean

DiAgNOSIS. - Shell large L to $80 \mathrm{~mm}$, thin-shelled, ovoid, laterally compressed, longer than high, tapering to anterior and posterior. Umbones low. Posterior dorsal area faintly delineated by shallow sulcus. Sculpture generally smooth with growth lines, sometimes with irregular short anterior and posterior marginal folds. Lunule small, narrow, triangular. Hinge line thin, two small bifurcate cardinal teeth in both valves, lateral teeth absent. Anterior adductor muscle scar long, narrow, curved, extends ventrally to past mid-line of shell, detached and widely separated from pallial line for nearly all of length. Pallial line narrow, entire. Shell interior with fine radial ridges. Inner shell margin smooth.

ETYMOLOGY. - Latin 'retro' - backwards and lucina in reference to similarity of Eocene species to the sole living species. Feminine.

DisTRIBUTION. - Western Indian Ocean particularly Mozambique.

Geological Range. - Lucina defrancei Deshayes, 1857, Eocene, Lutetian, Paris Basin (Fig. 6I-N) is very similar to $R$. voorhoevei n. comb. in shape, external sculpture, hinge teeth, and characters of anterior adductor muscle scar.

\section{REMARKS}

Previously included in Eomiltha, $R$. voorhoevei n. comb. differs from the type species by a number of characters. In shell outline, $R$. voorhoevei $\mathrm{n}$. comb. tapers posteriorly compared with $E$. contorta that is posteriorly truncate with a shallow sinus. The shell exterior is smooth compared with the more rugose Eomiltha, the anterior adductor scar is thinner and longer and the cardinal teeth smaller. In Retrolucina n. gen. the pallial line lacks the posterior angle towards the posterior adductor scar of Eomiltha contorta. Although Retrolucina n. gen. and Eomiltha are clearly related such morphological differences within living lucinids would suggest different generic placement. This is demonstrated by the various laterally compressed lucinids (e.g. Gloverina, Taylorina, Dulcina, Elliptiolucina) described from Indonesia and Philippines by Cosel \& Bouchet (2008) with several of these later corroborated by molecular analyses (Taylor et al. 2011, 2014, 2016).

An Eocene (Lutetian) species usually referred to Eomiltha is Lucina defrancei Deshayes, 1857 (synonym L. cuvieri Bayan, 1870) from the Paris Basin (Figs 6I-N; 7C, D) it 


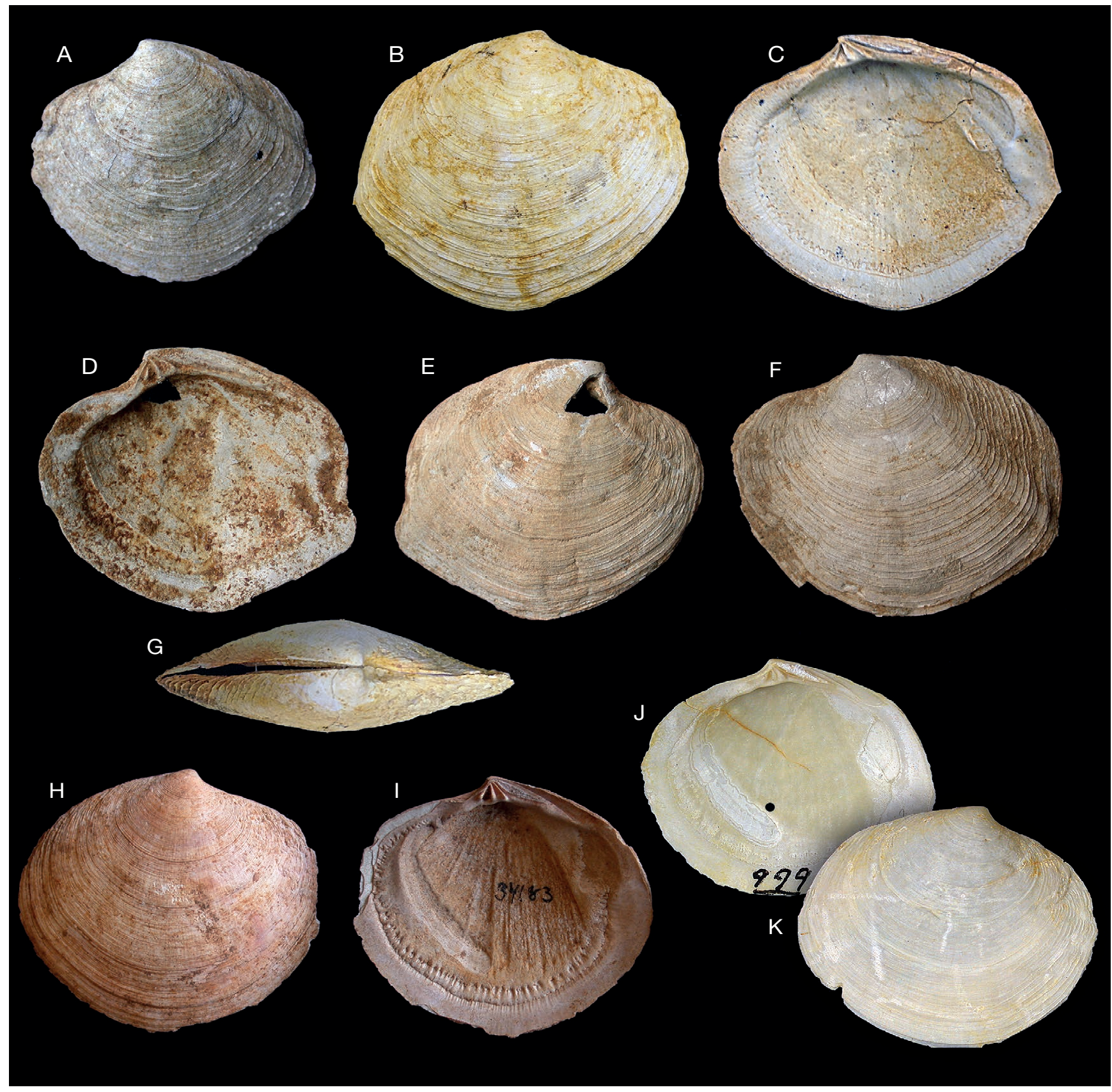

FIG. 5. - Eomiltha Cossmann, 1912 fossils: A, Eomiltha alburgensis (Vincent, 1930) exterior of left valve, Paleocene, Danian, Calcaire de Mons, Mons, Belgium, (RBINS IG 5496), L 32 mm; B, C, Eomitha contorta (Defrance, 1825), exterior and interior of right valve, Paleocene, Thanetian, Abbecourt, Oise, France (MNHN), L $52 \mathrm{~mm}$; D-F, Eomitha contorta (Defrance, 1825) interior and exterior of right valve and exterior of left valve, Paleocene, Thanetian, Sables de Bracheux, Beauvais, France, (RBINS IG 8260), L 43 mm; G, Eomiltha contorta dorsal view, Abbecourt, (MNHN), L 54 mm; H, I, 'Eomiltha' pandata (Conrad, 1833), Eocene (mid.), Gosport Sand, Claiborne Formation, Alabama, USA (PRI 34183), L 34 mm; J, K, 'Eomiltha' scolaroi Vokes 1969b, holotype, (USNM 646423), early Miocene, Chipola Formation, Farley Creek, Calhoun Co. Florida, USA, L 32.6 mm.

is very similar to Retrolucina voorhoevei $\mathrm{n}$. comb. in shell characters and we regard it as congeneric and an antecedent. Despite an extensive literature and collection search we failed to find any species resembling $R$. defrance $i$ and $R$. voorhoevei n. comb. recorded from deposits between the Eocene and present day.

Further back in geological time we previously (Taylor \& Glover 2000, 2006) compared Illiona prisca (Hisinger, 1837) from the Silurian of Gotland, Sweden with $R$. voorhoevei n. comb., it has a similar flat-shelled, elongate-ovate shape and internally has a very long anterior adductor muscle scar that extends posteriorly to the midline of the shell. The resemblance in shape is remarkable but, in the absence of any fossil record of similar forms from the later Palaeozoic through the Mesozoic, likely results from morphological convergence rather than phylogenetic continuity. 


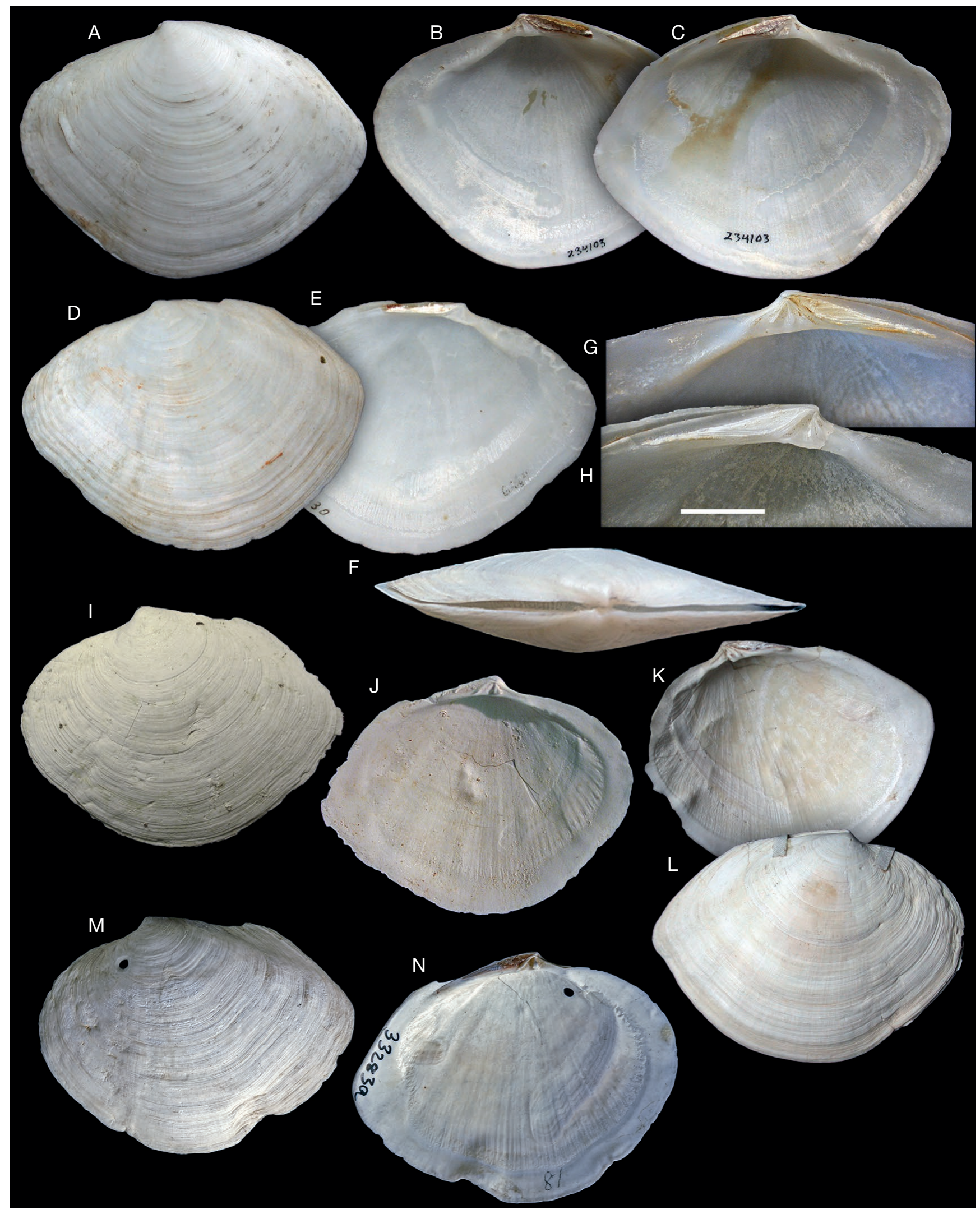

FiG. 6. - A-H, Retrolucina voorhoevei n. comb. (Deshayes, 1857), Recent; and I-N, R. defrancei (Deshayes, 1857), Eocene; A-C, exterior of right and interiors of right and left valves, Mozambique (ANSP 234103), L $70 \mathrm{~mm} ; \mathbf{D}, \mathbf{E}$, exterior and interior of left valve, Mozambique (USNM 628930), L $78 \mathrm{~mm}$; F, dorsal view (NHMUK 20170373), L $78 \mathrm{~mm} ; \mathbf{G}, \mathbf{H}$, details of hinge of right and left valves (NHMUK 20170373), scale bar, $10 \mathrm{~mm}$; I, J, Retrolucina defrancei (Deshayes, 1857) exterior and interior of left valve Eocene, Lutetian, Chaumont-en-Vexin, Oise, France (MNHN.F.J07396), L 35 mm; K, L. Retrolucina defrancei (Deshayes, 1857), Eocene, Lutetian, Chaussy, Seine et Oise, France, (RBINS IG10591), L 71 mm; M, N, Retrolucina defrancei (Deshayes, 1857), Eocene, Lutetian, Parnes, France, Deshayes collection (NHMUK $33283 a)$, L 50.4 mm. 

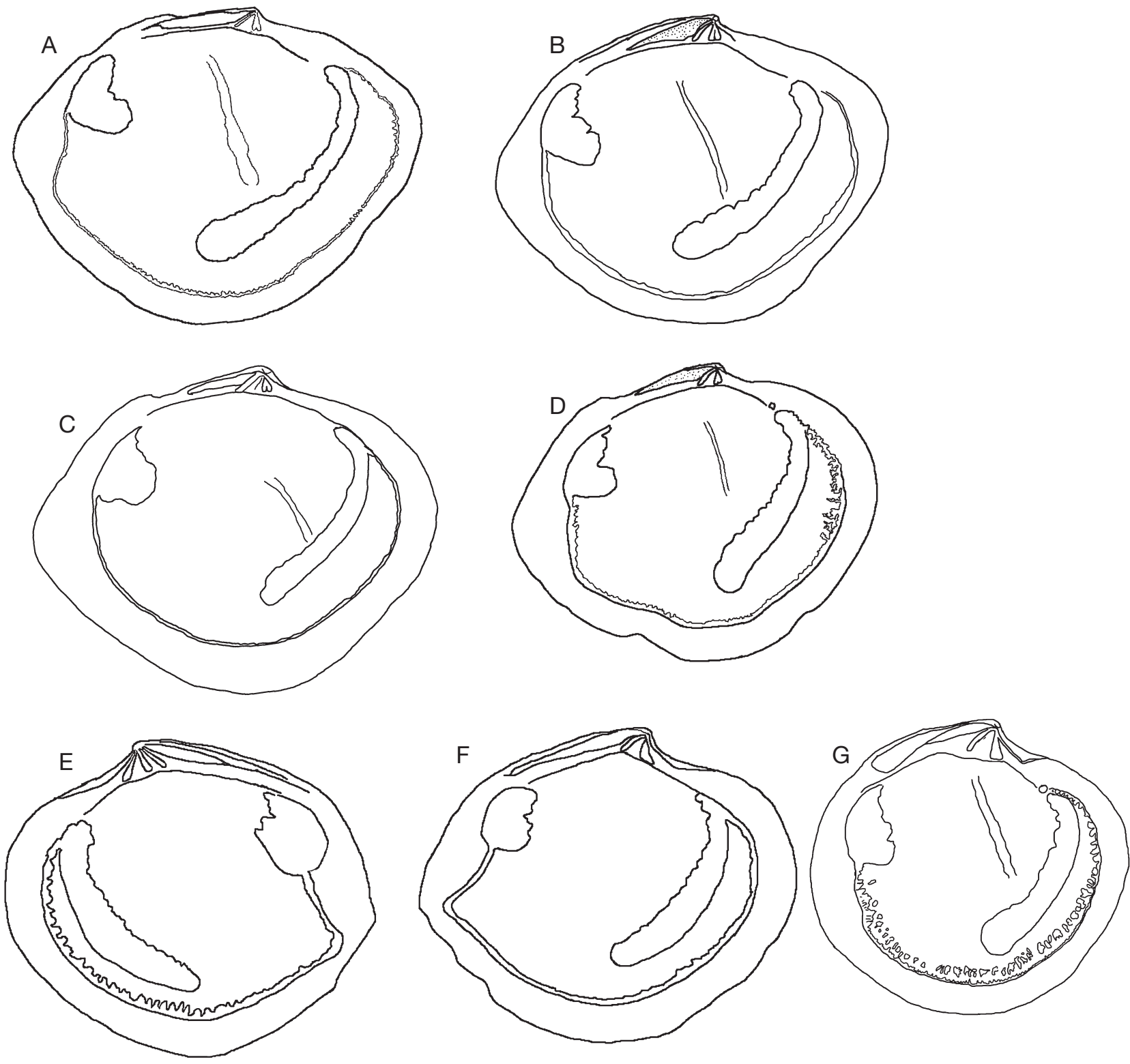

FIG. 7. - Eomiltha Cossmann, 1912 and Retrolucina n. gen., outline drawings of interiors of valves: A, Retrolucina voorhoevei n. comb. (Deshayes, 1857), Recent, Mozambique (USNM 628930); B, Retrolucina voorheoevi Recent, Mozambique (ANSP 234103); C, Retrolucina defrancei (Deshayes, 1857) Eocene, Lutetian, Chaumont-en-Vexin, France (MNHN.F.J07396); D, Retrolucina defrancei (Deshayes, 1857) Eocene. Lutetian, Parnes (NHMUK 33283a); E, F, Eomiltha contorta (Defrance, 1825) Paleocene, Thanetian, Abbecourt (MNHN); G, 'Eomiltha' pandata (Conrad, 1833) Eocene, Claiborne Formation, USA (NHMUK L 4402). Not to scale.

Retrolucina voorhoevei (Deshayes, 1857) n. comb. (Figs 6A-H; 7A, B)

Lucina voorhoevei Deshayes, 1857: 106, pl. 2, fig, 1. Holotype not located. Dance (1986: 154) lists 1872 sales catalogue of J. Voorhoeve collection where the holotype of Lucina voorhoevei was sold to H. C. R. van Lannep and then later listed in the 1876 sale catalogue of his collection (Jutting 1939) but its subsequent whereabouts is unknown.

Lucina mirabilis Dunker, 1865: 77, pl. 26, figs 7-9.

Gibbolucina (Eomiltha) voorhoevei - Chavan 1938: 93. - Kilburn 1974: 343, figs 6, 7.
Eomiltha voorhoevei-Oliver 1995: 236, fig. 1029. - Huber 2015: 106, 458.

TYPE LOCALITY. - Not given in original but cited as Mozambique by Heukolom 1866.

MATERIAl EXAMINED. - Algoa Bay (unlikely) (NHMUK 20170373); Mozambique (USNM 628930); Mozambique (ANSP 234103); Mozambique: Mucoque, near Vilanculos (MNHN).

Distribution. - Mozambique: Mucoque (MNHN), Inhassoro, Mucoque and Bazaruto Island (Kilburn 1974); Madagascar: NW Madagascar (ANSP); Kenya: Ukunda (Huber 2015); Oman: Masirah (Oliver 1995), Muscat (NMW BV6059). 
HABITAT. - No live collected specimens are known. Most records are beach collected and the species is assumed to live subtidally but Huber (2015) records dead shells at $5 \mathrm{~m}$ depth in southern Kenya.

\section{DESCRIPTION}

Shell large, $\mathrm{L}$ to $80 \mathrm{~mm}$, ovoid, tapering to anterior and posterior, thin shelled, relatively flat T $8.3 \mathrm{~mm}$ single valve. Umbones small, low. Posterior dorsal area faintly delineated by shallow sulcus. Sculpture generally smooth with irregular growth lines. Lunule small, narrow, triangular. Ligament short, set in shallow groove. Hinge line thin, RV with two cardinal teeth the posterior bifurcate, anterior tooth smaller, LV with two cardinal teeth, anteriormost bifurcate; lateral teeth absent in both valves. Anterior adductor muscle scar long, narrow, curved, extends ventrally to past mid-line of shell, detached and widely separated from pallial line for nearly all of length. Posterior adductor scar reniform. Pallial line narrow, entire. Pallial blood vessel scar visible, terminating ventrally at lower part of anterior adductor scar. Shell interior with fine radial ridges and sometimes exposed organic layers. Shell outside pallial line glossy, margin smooth.

\section{REMARKS}

Among living Lucinidae Retrolucina voorhoevei n. comb. has an unusual, elongate, laterally compressed shell shape that is only matched by some deep water taxa such as Gloverina and Elliptiolucina (Cosel \& Bouchet, 2008) or Jorgenia (Taylor \& Glover, 2009) but these have short anterior adductor muscle scars and molecular results show they belong in the Myrteinae (Taylor et al. 2014, 2016). By contrast, although details of habitat are lacking, the presence of dead shells on beaches suggests that $R$. voorhoevei n. comb. is a shallow subtidal species. The Eocene congener, $R$. defrancei, was also a shallow water species recorded by Courville et al. (2012) from the Paris Basin at Damery (Lutetian), in beds associated with cerithiid and potamidid gastropods.

\section{Subfamily MONitilorinae Taylor \& Glover, 2011}

\section{REMARKS}

This subfamily was introduced for subcircular lucinids with closely spaced commarginal lamellae and fine radial ribs in the interspaces. The single species included in molecular analyses, Monitilora ramsayi (Smith, 1885), forms a separate branch with an unstable position (Taylor et al. 2011, 2014, 2016) but never aligns within any other of the major clades of Lucinidae.

\section{Genus Monitilora Iredale, 1930}

Monitilora Iredale, 1930: 390.

TYPE SPECIES. — Lucina ramsayi Smith, 1885 (original designation).

DiagnOSIS. - Shell white, subcircular, $\mathrm{H}$ to $25.0 \mathrm{~mm}$, moderately inflated, light-shelled. Sculpture of fine, rounded, closely spaced, commarginal lamellae with fine radial riblets in the interspaces.
Lunule, sunken, asymmetric with greater part in left valve. Hinge plate narrow, right valve with a single small cardinal tooth, small anterior lateral tooth; left valve with two small cardinal teeth and no lateral teeth. Anterior adductor scar medium length, ventrally detached for $1 / 2$ of length, dorsal part much broader than ventral extension. Pallial line entire, shell margin smooth.

INCLUDED SPECIES. — M. ramsayi (Smith, 1885), M. subtilis Glover \& Taylor, 2016, M. sepes (Barnard, 1964), M. bonneti (Cossmann, 1923).

Geological Range. — ?Early Cretaceous, Paleocene to Recent.

\section{REMARKS}

Originally described from eastern Australia (M. ramsayi), species are now known from the Philippines (M. subtilis) and a poorly documented species from southern India, originally described from Pliocene deposits (M. bonneti), as well as $M$. sepes from the southwestern Indian Ocean. An undescribed species is present in collections (NHMUK) from western Thailand. It should be noted that, excepting $M$. ramsayi, various Australian species that have been placed in Monitilora (e.g. Lamprell \& Whitehead 1992) belong in other genera.

Shells with characters very similar to the living Monitilora ramsayi and other species can be recognised from the early Paleocene. For example, Monitilora duponti (Cossmann, 1908) from the Calcaire de Mons, Belgium (Danian) (Fig. 8A, B) was previously classified in the genus by Chavan (1937-1938), and also Monitilora concinna (Deshayes 1857) from the Thanetian of the Paris Basin. Recorded from the Eocene of the Paris Basin (Lutetian-Bartonian) are Monitilora elegans (Defrance, 1824) and Monitilora baudoni (Deshayes, 1857) (Fig. 8C, D). The post-Eocene fossil record of Monitilora is scant and poorly documented; species are known from Miocene (Badenian) of Poland (Studencka 1986), Japan (Itoigawa 1957), Pliocene of India (Cossmann 1923) and Pliocene of South Australia (Ludbrook 1955).

Molecular analysis (Taylor et al. 2011) suggests that Monitilorinae split from other lucinids at least by the mid-Cretaceous. Some Monitilora-like bivalves were present in the Mesozoic but have been placed in Mesomiltha or Myrtea. Examples are Mesomiltha cf fallax, from the Cretaceous (Cenomanian) of India (Kendrick \& Vartak 2007, figs 13I-M) and Myrtea? monobeana Tashiro \& Kozai (1988: 36, pl. 2 figs 29-32, text Fig. 2) from the early Cretaceous of Japan.

\section{Monitilora sepes (Barnard, 1964) \\ (Fig. 8E-Q)}

Phacoides sepes Barnard, 1964: 25, fig. 6b.

Gonimyrtea sepes - Kilburn 1973: 701.

Monitilora sepes - Huber 2015: 445.

TYPE MATERIAL. - 3 syntypes (SAM A9529).

Type locality. - Off Morewood Cove, Natal, 27 fms (49 m).

Material eXamined. - Mozambique. Inhaca Island, Sud Ponta Abril, Expédition INHACA, 2011 stn MD17, 2609.1'S, 32 58.0'E, 33-39 m, 3 v, 01.12.2011 (MNHN). Inhaca Island, devant La Passe, 


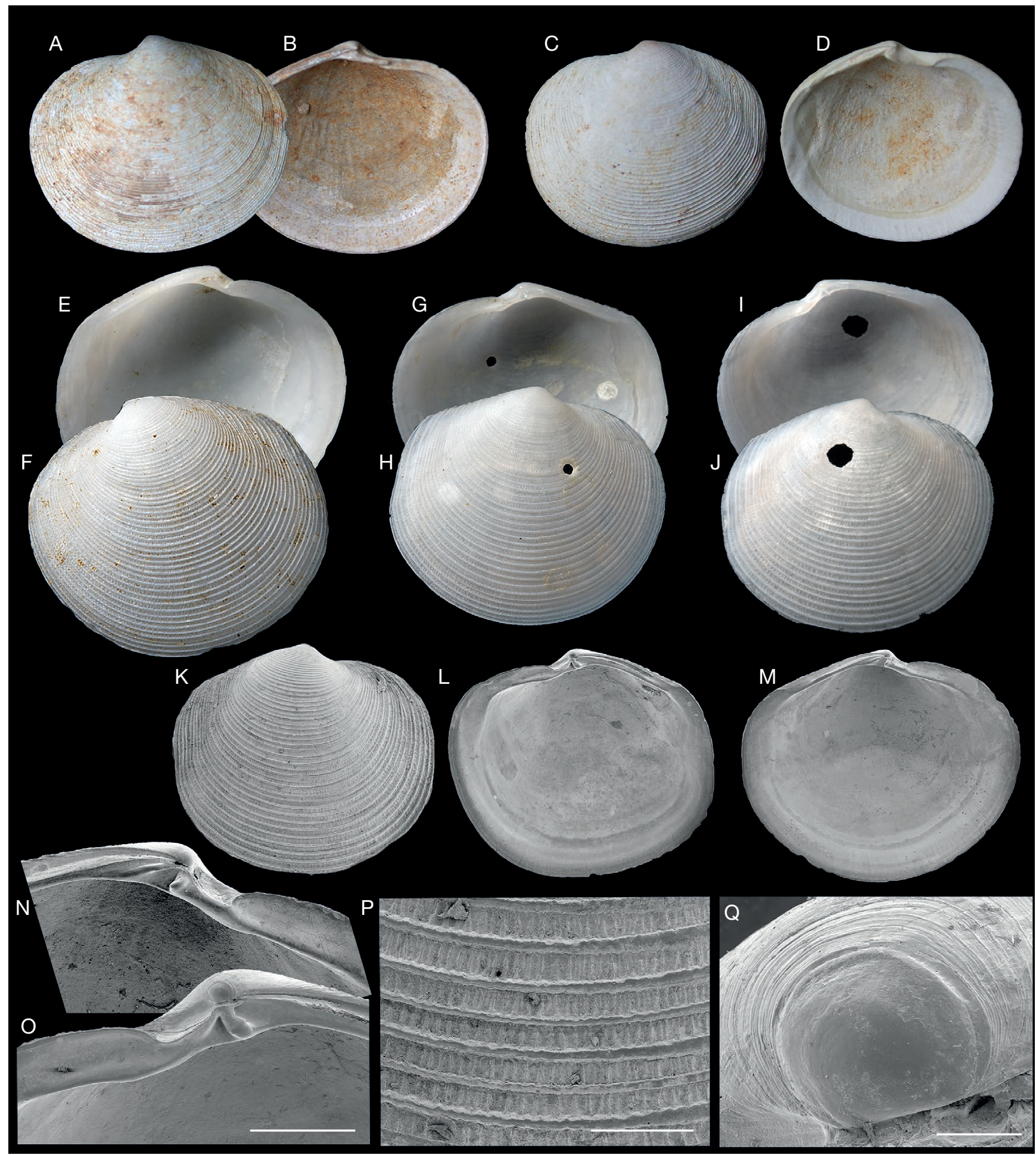

FiG. 8. - Monitilora Iredale, 1930, Palaeogene fossils (A-D) and Monitilora sepes (Barnard, 1964) Inhaca, Mozambique (E-Q): A, B, Monitilora duponti (Cossmann, 1908) Paleocene, Danian, Calcaire de Mons, Mons Puits Coppée, Belgium (RBINS I.G. 6544), L $17.5 \mathrm{~mm}$; C, D, Monitilora obliqua baudoni (Deshayes, 1857) Eocene, Lutetian, Amblainville, Oise, France, Chavan collection (RBINS I.G. 21.735), L 18 mm; E, F, Monililora sepes exterior and interior of left valve, Inhaca stn MD11, L $15 \mathrm{~mm} ; \mathbf{G}, \mathbf{H}$, exterior and interior of right valve, Inhaca stn MD15, L $12.1 \mathrm{~mm}$; I, J, exterior and interior of right valve, Inhaca stn MD15, L 10.2 mm $\mathbf{K}, \mathbf{L}$, exterior and interior of right valve, Inhaca stn MD15, L $10.1 \mathrm{~mm} ; \mathbf{M}$, interior of left valve, Inhaca stn MD15, L $8.4 \mathrm{~mm} ; \mathbf{N}, \mathbf{O}$, detail of hinge teeth of left and right valves of $\mathbf{H}$, I; P, detail of external sculpture of $\mathbf{K}$; $\mathbf{Q}$, protoconch of $\mathbf{H}$. Scale bars: N, O, $1.0 \mathrm{~mm}$; P, $500 \mu \mathrm{m} ; \mathbf{Q}, 100 \mu \mathrm{m}$.

Expédition INHACA, stn MD11, 260․ㅇ's, 3259'E, 24-32 m, 5 v, 30.XI.2011 (MNHN). Devant La Passe, stn MD15, 2605.0’' $32^{\circ} 59^{\prime} \mathrm{E}, 35 \mathrm{~m}, 5$ v, 01.XII.2011(MNHN).
South Madagascar. Expédition ATIMO VATAE, secteur de Lavanono, stn BP34, $25^{\circ} 25.8^{\prime} \mathrm{S}, 4^{\circ} 55.4^{\prime} \mathrm{E}, 14-15 \mathrm{~m}, 1 \mathrm{pv}$ (L $\left.13.9 \mathrm{~mm}\right)$ $(\mathrm{MNHN})$ 


\section{DESCRIPTION}

Shell white, subcircular, L to $15 \mathrm{~mm}$, moderately inflated, light-shelled, posterior dorsal area shallowly demarcated. Sculpture of fine, low, closely spaced, commarginal lamellae, interspaces with radial riblets. Protoconch PI + PII $=264 \mu \mathrm{m}$, P II a narrow $17 \mu \mathrm{m}$ rim (Fig. 8Q). Lunule short, scooped. Hinge plate narrow, RV with single small cardinal tooth and a small anterior lateral tooth, LV with two small cardinal teeth. the posteriormost longer and thinner, no lateral teeth. Anterior adductor scar medium length, detached for $1 / 2$ of length, dorsal part much broader than ventral extension. Pallial line entire, shell margin smooth.

\section{REMARKS}

In the original description this species was poorly illustrated with only drawings of the hinge of one valve and a small portion of shell sculpture. It is therefore unsurprising that its affinities remained uncertain. The shell sculpture and hinge match with the shells from the Inhaca samples and placement in Monitilora can be confirmed. Huber's (2015) generic assignment followed advice from present authors. The Mozambique and Natal records are distant from other recorded Monitilora species from eastern Australia, Philippines, Thailand and southern India and represent a considerable range extension for the genus. Apart from the eastern Australian $M$. ramsayi, shells are rarely present in museum collections.

\section{DISCUSSION}

There are species of lucinid genera living today only in the western Indian Ocean that have origins and congeners in the early Palaeogene of northwestern Europe: Barbierella from the Paleocene (mid-Danian $60 \mathrm{ma}$ ) and Retromiltha and Gibbolucina from the Eocene (Lutetian c. $45 \mathrm{ma}$ ). Barbierella species have always been rare with a patchy fossil record to the mid-Miocene. Retrolucina n. gen. has no known fossil record between the Eocene and present day and the most recent fossil record of Gibbolucina species comparable to our generic concept dates from the Miocene (Aquitanian) of southern France. Monitilora species are also known from the Paleocene and maybe even earlier, the few living species are uncommon but more widely distributed in the Indo-West Pacific with the Mozambique species, $M$. sepes, isolated from other congeners. These genera are considerably older $(62-45 \mathrm{ma})$ than the median ages for living Indo-West Pacific bivalves documented by Flessa $\&$ Jablonski (1996) i.e., total $8.6 \mathrm{ma}$ and $14.7 \mathrm{ma}$ for genera with a fossil record. By comparison, other Lucinidae that are abundant in coral reef faunas of the tropical Indian Ocean such as Codakia Scopoli, 1777, Ctena Mörch, 1861 and Pillucina Pilsbry, 1921 date from the Miocene or Pliocene (Taylor et al. 2011), with, for example, the dominance of Codakia species in tropical seagrass communities dating only from the early Pliocene.

The survival of Retromiltha, Barbierella and Gibbolucina species in the Mozambique Channel and a few other locations in the western Indian Ocean runs counter to conventional wisdom concerning species attributes that confer resistance to extinction (McKinney 1997; Harnik et al. 2012; Finnegan et al. 2015). That is their populations are small, with seemingly narrow distributional ranges that have been so for considerable periods of time. The fossil record is so sporadic that they could be regarded as 'Lazarus taxa' (Jablonski 1986; Fara 2001), that is genera thought to have become extinct but reappear at more recent horizons. Although their survival is problematic, populations of the bivalves could have been tucked away in small refugia with low preservational potential or less likelihood of subsequent discovery. Low latitude Palaeogene and Neogene faunas, are generally less well preserved and less well researched than the excellent preservation of the Eocene faunas of the Paris Basin or the Miocene molluscs of the Aquitaine Basin and northern Italy, with shells often dissolved away and preserved as molds and casts with small species particularly vulnerable to loss.

How did these genera of western European origin end up in the western Indian Ocean? Closure of Tethyan Seaway in the Middle East that connected the proto Mediterranean and eastern Atlantic with the Indian Ocean occurred in early Miocene (Late Burdigalian c. $19 \mathrm{ma}$ ) with another shortlived marine connection in the mid-Miocene (Langhian c. $14 \mathrm{ma}$ ) although differentiation of faunas between the western and eastern Tethys was apparent during the Oligocene (Harzhauser et al. 2007). Extinction of the many Mediterranean and eastern Atlantic taxa followed during the Late Miocene. Various analyses have demonstrated that centres of marine diversity moved from Western Tethys in the Eocene, eastwards to Arabia in the Oligocene and early Miocene and to the central IWP from the later Miocene to Recent (Harzhauser et al. 2008; Renema et al. 2008). We suggest that Gibbolucina, Barbierella and Retrolucina n. gen. were confined to the western Indian Ocean at least by the middle Miocene and maybe earlier. The northwards drifting Indian land mass and the north-south trending Mascarene Banks likely formed a barrier to eastwards dispersal isolating the western Indian Ocean faunas (see Obura 2015: fig. 1). Unfortunately, there is no fossil evidence, so far, of these long-lived genera in Cenozoic deposits of the western Indian Ocean.

In comparison to the lucinids, Obura $(2012,2015)$, in a study of the biogeographic history of western Indian Ocean corals, documented several 'relict' genera of Palaeogene, western Tethys origin surviving in the region particularly the Mozambique Channel and East African coast but which had failed to spread to the central IWP. He developed the hypothesis that the tectonically and oceanographically stable Mozambique Channel preserves old lineages, the most publicised being the coelacanth, Latimeria chalumnae Smith, 1939 (Fricke \& Hissmann 2000).

Most living records of these 'old' lucinid genera occur in the Mozambique Channel and on the eastern African coast. The separation of Madagascar from Africa to form the Mozambique Channel occurred in the early Creta- 
ceous c. 120-130 ma (Rabinowitz et al. 1983; McCall 1997; Rabinowitz \& Woods 2006) and its configuration has remained generally stable since that time within a relatively tectonically inactive western Indian Ocean. The channel is notable for complex eddy systems (Schouten et al. 2003; Sabarros et al. 2009) that likely result in larval retention and a possible resilience of communities and populations. Evidence from the protoconchs of Lucinidae shows that there is considerable variation in larval development and potential for dispersal; some species have a large protoconch II with many growth increments suggesting prolonged planktonic lives while others show little or no growth of PII suggesting rapid settlement or non-feeding planktonic stage (Glover \& Taylor 2016). Both Barbierella louisensis and Gibbolucina zelee n. sp. have protoconchs with little growth in PII (Figs 2S, 4W), as does Monitilora sepes (Fig. 8Q) but the morphology of the larval shell of Retrolucina voorhoevei $\mathrm{n}$. comb. is not known. Our evidence suggests limited dispersal abilities of the species.

In addition to the main subjects of this paper Loripes clausus (Philippi, 1848) is an often abundant species in seagrass beds ranging from Red Sea and eastern coast of Africa and Western Madagascar (Macnae \& Kalk 1962). This is the only species of Loripes living in the Indo-West Pacific realm but its distribution is confined to the western Indian Ocean particularly eastern Africa and western Madagascar. Its sister species (Taylor et al. 2016) is Loripes orbiculatus Poli, 1791, from the Mediterranean and eastern Atlantic (UK to Mauritania). In contrast to Gibbolucina, Retrolucina n. gen. and Barbierella, the earliest fossil Loripes Poli, 1791 date from the early Miocene (Loripes dujardini (Deshayes, 1850), Aquitanian). The disjunct distribution of the two Loripes species may date from the closure of the Tethyan seaway in the early Miocene. Another species of Loripes, L. araiogramma Oliver \& Chesney, 1997, was described from southern Oman but Huber (2015) placed it in Lucinella as it has obliquely incised sculpture not present in Loripes species. Lucinella divaricata (Linnaeus, 1758) from the Mediterranean and Eastern Atlantic is the only other recognised species of the genus that first appeared in the mid-Miocene. The Oligocene genus Paralucinella Chavan, 1951 (type species Lucina undulata Lamarck, 1806) lacks the internal ligament of Lucinella and Loripes and belongs in a different clade. Also similar in history is the divaricately sculptured Bourdotia (type species Lucina bourdoti Cossmann, 1882) first described from early Eocene to Oligocene of Europe but with a single surviving species B. boschorum (Dekker \& Goud, 1994) living around southern Oman.

Another rare lucinid from the western Indian Ocean is Rasta lamyi (Abrard, 1941) recorded from the northern Red Sea and off northern Madagascar (Glover \& Taylor 1997; Taylor et al. 2005), the only other known species is $R$. thiophila (Taylor \& Glover, 1997) from the Houtman Abrolhos and Shark Bay area of Western Australia. This distribution is puzzling but recent predictive ocean drift maps of marine debris (PlasticAdrift.org) show that items entering the water in mid-Western Australia will drift towards Madagascar and eastern Africa. A different history is suggested for Lucina roscoeorum (Kilburn, 1974) distributed along the eastern African coast from Natal to Kenya, (Inhaca, Mozambique samples MNHN) is the only species of the genus living in the Indo-West Pacific Oceans. The nearest similar species are Lucina carnosa Dunker, 1858 from South Africa and, L. adansoni d'Orbigny, 1840 and L. goreensis (Jaeckel, 1927) from West Africa. This distribution of species suggests that $L$. roscoeorum may have originated by migration from southern Africa.

For lucinid bivalves our results have highlighted the presence of endemic species and genera in the western Indian Ocean and in particular the Mozambique Channel area and these add to increasing evidence of the southwestern Indian Ocean as a distinct biogeographic realm (Houart \& Héros 2013, 2015; Hoareau et al. 2013; Obura 2015) with survivors dating from before the Miocene closure of the Tethyan Seaway.

\section{Acknowledgements}

Grateful thanks are due to Philippe Bouchet, Philippe Maestrati and Virginie Héros (MNHN) and Paul Callomon (ANSP) for loan of specimens. We thank Harriet Wood (NMW) for images of the holotype of Barbariella scitula; Jean-Michel Pacaud (MNHN) for images of B. barbieri, help with fossil collections and advice on their age; Daniele Ormezano (MRSN Turin) for images of the holotype Here miobarbieri; Alison Miller (AMS) for images of Viader syntypes and Pierre Lozouet (MNHN) for images of Miocene Gibbolucina. Bernard Thomassin provided information on Madagascar and Banc de la Zélée collection stations. For access to collections in their care we thank Annelise Folie (RBINS); Jon Todd (NHMUK); Greg Dietl and Paula Mikkelsen (PRI); Ellen Strong (USNM); Liz Harper and Matt Riley (SM) .

The BENTHEDI cruise (Principal Investigator Bernard Thomassin) took place on board R.V. Suroit, operated by IFREMER. The MIRIKY and ATIMO VATAE expeditions were part of a cluster of Mozambique-Madagascar 2009-2010 expeditions under the umbrella of the "Our Planet Reviewed" programme conducted by Muséum national d'Histoire naturelle (MNHN; Principal Investigator Philippe Bouchet) and Pro-Natura International (PNI) in partnership with Institut d'Halieutique et des Sciences Marines, University of Toliara (IH.SM) and the Madagascar bureau of Wildlife Conservation Society (WCS). The organizers thank the Total, Prince Albert II and Niarchos Foundations for their funding the expeditions. The INHACA 2011 workshop was carried by MNHN in collaboration with Universidade Eduardo Mondlane, Maputo, and the organizers thank Mandë Holford and Jose Rosado for their key role in funding and logistics. We are grateful to two reviewers and the editorial staff of Zoosystema for their careful attention to detail with the resultant improved text. 


\section{REFERENCES}

BARNARD K. H. 1964. - The work of the s.s. Pieter Faure in Natal waters, with special reference to the Crustacea and Mollusca; with descriptions of new species of Mollusca from Natal. Annals of the Natal Museum 16: 9-29.

BRETSKY S. S. 1976. - Evolution and classification of the Lucinidae (Mollusca; Bivalvia). Palaeontographica Americana 8 (50): 219-337.

CHAVAn A. 1937. - Essai critique de classification des lucines. Journal de Conchyliologie 81 (2): 133-153; 81 (3): 193-216; 81 (4): 237-282.

Chavan A. 1938. - Essai critique de classification des lucines. Journal de Conchyliologie 82 (1): 59-97; 82 (2):105-130; 82 (3): 215-241.

ChAVAN A. 1969. - Superfamily Lucinacea Fleming, 1828, in Moore R. C. (ed.), Treatise on Invertebrate Paleontology, Part $N$, Mollusca 6, Bivalvia, volume 2., Geological Society of America and University of Kansas, Boulder, Colorado: N491-N518.

COSEL R. vON \& BOUCHeT P. 2008. - Tropical deep-water lucinids (Mollusca: Bivalvia) from the Indo-Pacific: essentially unknown, but diverse and occasionally gigantic, in Héros V., COWIE R. \& Bouchet P. (eds) Tropical Deep Sea Benthos, volume 25. Muséum national d'Histoire naturelle, Paris, 806 p. (Mémoires du Muséum national d'Histoire naturelle ; 196): 115-213.

CoSSMANN M. 1904. — Mollusques éocéniques de la Loire-Inférieure. Tome III, fasc. 1. Bulletin de la Société des Sciences naturelles de l'Ouest de la France, 2e sér. 4: 149-213.

Cossmann M. 1913. - Appendice No 5 au catalogue illustré des coquilles fossiles de l'Éocène des environs de Paris. Annales de la Société royale zoologique et malacologique de Belgique 49: 19-258, pls 1-8, text figs 1-154.

Cossmann M. 1923. - Faune pliocénique de Karikal (Inde Française), pélécypodes. Journal de Conchyliologie 68: 85-150.

Cossmann M. \& Peyrot A. 1912. - Conchologie néogénique de l'Aquitaine. Actes de la Société linnéenne de Bordeaux 65 (4): 179-333.

Cossmann M. \& Pissarro G. 1904. - Faune éocénique du Cotentin. 5e article. Bulletin de la Société géologique de Normandie 23: 11-29.

COSSMANN M. \& PISSARRO G. 1904-1906. — Iconographie complète des coquilles fossiles de l'Éocène des environs de Paris. Volume 1 Pélécypodes, Hermann, Paris, pls 1-45.

Courville P., Pacaud J.-M., Merle D. \& Lebrun P. 2012. — Le Lutétien de Damery (Marne, France) géologie, environnements, associations de bivalves et gastéropodes. Fossiles, hors-série III: 57-71.

DANCE S. P. 1986. - A history of shell collecting. E. J. Brill, Leiden. $265 \mathrm{p}$.

DeshaYes G. P. 1857. - Note sur une nouvelle lucine, et description de l'espèce. Journal de Conchyliologie 6: 104-107.

DiCKERSON R. E. 1916. - Stratigraphy and fauna of the Tejon Eocene of California. University of California Publications, Bulletin of the Department of Geology 9 (17): 363-524.

DunKer G. 1858-1878. - Novitates Conchologicae. Abt 2 Mollusca Marina. Theodor Fischer, Cassel: 1-144, pls 1-45.

FARA E. 2001. - What are Lazarus taxa? Geological Journal 36: 291-303. https://doi.org/10.1002/gj.879

Finnegan S., ANDERSON S. C., HARniK P. G., Simpson C., TitTenSOR D. P., Byrnes J. E., Finkel Z. V., LindBerg D. R., HSiAng LiOW L., LOCKWOOD R., LOTZE H. K., MCCLAIN C. R., MCGUiRE J. L., O'deA A. \& PAndolfi J. M. 2015. - Paleontological baselines for evaluating extinction risk in the modern oceans. Science 348: 567-570. https://doi.org/10.1126/science.aaa6635

FLESSA K. W. \& JABLONSKI D. 1996. — The geography of evolutionary turnover: a global analysis of extant bivalves, in JABLONSKI D., ERWIN D. H. \& LipPS J. H. G. (eds). Evolutionary Paleobiology. University of Chicago Press, Chicago: 376-397.

FricKe H. \& HisSMANN K. 2000. - Feeding ecology and evolutionary survival of the living coelacanth Latimeria chalumnae. Marine Biology 136: 379-386. https://doi.org/10.1007/s002270050697
Glibert M. \& Van De Poel L. 1973. - Les Bivalvia Danien et du Montien de la Belgique. Mémoires de l'Institut royal des Sciences naturelles de Belgique 175: 1-89.

Glover E. A. \& TAYLOR J. D. 1997. - New species and records of Rastafaria and Megaxinus (Bivalvia: Lucinidae) from the Western Indian Ocean and Red Sea, with a reappraisal of Megaxinus. Journal of Conchology 36: 1-18.

GLOVER E. A. \& TAYLOR J. D. 2007. — Diversity of chemosymbiotic bivalves on coral reefs: Lucinidae (Mollusca, Bivalvia) of New Caledonia and Lifou. Zoosystema 29 (1): 109-181.

Glover E. A. \& TaYlor J. D. 2016. — Lucinidae of the Philippines: highest known diversity and ubiquity of chemosymbiotic bivalves from intertidal to bathyal depths (Mollusca: Bivalvia). in Héros V., Strong E. \& Bouchet P. (eds), Tropical DeepSea Benthos 29. Muséum national d'Histoire naturelle, Paris, 463 p. (Mémoires du Muséum national d'Histoire naturelle ; 208): 65-234.

HaRNiK P. G. 2011. — Direct and indirect effects of biological factors on extinction risk in fossil bivalves. Proceedings of the National Academy of Sciences 108: 13594-13599. https://doi. org/10.1073/pnas.1100572108

Harnik P. G., Simpson C. \& Payne J. L. 2012. — Long-term differences in extinction risk among the seven forms of rarity. Proceedings of the Royal Society B, Biological Sciences 279: 49694976. https://doi.org/10.1098/rspb.2012.1902

Harzhauser M., Kroh A., Mandic O., Piller W. E., Gohlich U., REsUTER M. \& BERNING B. 2007. - Biogeographic responses to geodynamics: a key study all around the Oligo-Miocene Tethyan Seaway. Zoologischer Anzeiger 246: 241-256. https:// doi.org/10.1016/j.jcz.2007.05.001

Harzhauser M., Mandic O., Piller W. E., Reuter M. \& Kroh A. 2008. - Tracing back the origin of the Indo-Pacific mollusk fauna: basal Tridacninae from the Oligocene and Miocene of the Sultanate of Oman. Palaeontology 51: 199-213. https://doi. org/10.1111/j.1475-4983.2007.00742.x

HeuKOlOm F. 1866. - Note sur l'identité des Lucina voorhoevei Desh. et L. mirabilis Dunker. Journal de Conchyliologie 14: 39-40.

Hoareau T. B., Boissin E., Paulay G., Bruggemann J. H. \& DaWSON M. 2013. - The Southwestern Indian Ocean as a potential marine evolutionary hotspot: perspectives from comparative phylogeography of reef brittle-stars. Journal of Biogeography 40: 2167-2179. https://doi.org/10.1111/jbi.12155

Houart R. \& Héros V. 2013. - Description of new Muricidae (Mollusca: Gastropoda) collected during the ATIMO VATAE expedition to Madagascar "Deep South". Zoosystema 35 (4): 503-523. https://doi.org/10.5252/z2013n4a5

Houart R. \& Héros V. 2015. - New species of Muricidae Rafinesque, 1815 (Mollusca: Gastropoda) from the Western Indian Ocean. Zoosystema 37 (3): 481-503. https://doi.org/10.5252/ z2015n3a4

Huber M. 2015. - Compendium of bivalves 2. Harxheim: ConchBooks, $907 \mathrm{p}$.

IREDALE T. 1930. - More notes on the marine Mollusca of New South Wales. Records of the Australian Museum 17: 384-407. https://doi.org/10.3853/j.0067-1975.17.1930.773

ITOIgAWA J. 1957. - On the Miocene Lucinidae from the Mizunami Group, Japan. Transactions and Proceedings of the Paleontological Society of Japan 25: 1-6.

JABLONSKI D. 1986. - Background and mass extinctions: the alternation of macroevolutionary regimes. Science 231: 129-133. https://doi.org/10.1126/science.231.4734.129

JUTTING W. S. S. VAN B. 1939. - A brief history of the conchological collections at the Zoological Museum of Amsterdam, with some reflections on 18th century shell cabinets and their proprietors, on the occasion of the centenary of the Royal Zoological Society "Natura Artis Magistra". Bijdragen tot de Dierkunde 27: 167-246. Kendrick G. W. \& VARTAK A. V. 2007. — Middle Cretaceous (Cenomanian) bivalves from the Karai Formaton, Uttattur Group, 
of the Cauvery Basin, south India. Records of the Western Australian Museum, Supplement 72: 1-101. https://doi.org/10.18195/ issn.0313-122x.72.2007.001-101

KILBURN R. N. 1973. - The type material of South African marine Mollusca in the Natal Museum collection. Part 1. Bivalvia. Annals of the Natal Museum 21: 697-711.

KILBURN R. N. 1974. - Taxonomic notes on South African marine Mollusca (4) Bivalvia, with descriptions of new species of Lucinidae. Annals of the Natal Museum 22: 335-348.

LAMARCK J. B. 1806. - Mémoires sur les fossils des environs de Paris (suite 6). Annales du Muséum d'Histoire naturelle 7: 130-139.

LAMPRELL K. \& WhiteheAd T. 1992. - Bivalves of Australia. Volume 1. Crawford House Press, Bathurst, Australia, 182 p.

LudBrooK N. H. 1955. - The molluscan fauna of the Pliocene strata underlying the Adelaide Plains. Part II - Pelecypoda. Transactions of the Royal Society of South Australia 78: 18-87.

LudBRoOK N. H. 1978. - Quaternary molluscs of the western part of the Eucla Basin. Bulletin Geological Survey of Western Australia 125: 5-286.

MCCALL R. A. 1997. — Implications of recent geological investigations of the Mozambique Channel for the mammalian colonization of Madagascar. Proceedings of the Royal Society of London B 264: 663-665. https://doi.org/10.1098/rspb.1997.0094

MCKINNEY M. L. 1997. - How do rare species avoid extinction? A paleontological view, in KUNIN W. E. \& GASTON K. J. (eds). The biology of Rarity. Chapman \& Hall, London: 110-129.

MACNAE W. \& KALK M. 1962. - The fauna and flora of sand flats at Inhaca Island, Moçambique Journal of Animal Ecology 31: 93-12. https://doi.org/10.2307/2334

Moore E. J. 1988. - Tertiary marine pelecypods of California and Baja California: Lucinidae through Chamidae. United States Geological Survey Professional Paper 1228-D: 1-46.

OBuRa D. 2012. - Evolutionary mechanisms and diversity in a western Indian Ocean center of diversity. Proceedings of the 12th International coral reef symposium, Cairns, Australia 9-13 July 2012. 3A. Evolution, biogeography and taxonomy: general session, $6 \mathrm{p}$.

OBURA D. 2015. - An Indian Ocean centre of origin revisited: Palaeogene and Neogene influences defining a biogeographic realm. Journal of Biogeography 43: 229-242. https://doi.org/10.1111/ jbi. 12656

Oliver P. G. 1995. - Bivalvia, in DANCE S. P. (ed.). Seashells of Eastern Arabia. Motivate Publishing, Dubai: 194-281.

Oliver P. G. \& ABOU-Zeid M. 1986. - Barbierella (Bivalvia: Lucinacea) a Tethyan relict species living in the Red Sea. Journal of Conchology 32: 221-224.

OrZECHOWSKI E. A., LOCKWOOD R., BYRnes J. E. K., ANDERSON S. C., Finnegan S., Finkel Z. V., Harnik P. G., Lindberg D. R., Liow L. H., Lotze H. K., Mcclain C. R., Mcguire J. L., O’dea A., Pandolfi J. M., Simpson C. \& Tittensor D. P. 2015. - Marine extinction risk shaped by trait-environment interactions over 500 million years. Global Change Biology 21: 3595-3607. https://doi.org/10.1111/gcb.12963

PaCAUd J.-M. \& LEDON D. 2007. — Sur les espèces de mollusques du Ludien (Priabonien, Éocène supérieur) du bassin de Paris introduites par Périer en 1941. Cossmanniana 11: 7-25.

Philippi R. A. 1847-1850. - Abbildungen und Beschreibungen neuer oder wenig gekannter Conchylien. Volume 3, T. Fischer, Cassel: 138 p.

RabinOWITZ P. D. \& Woods S. 2006. - The Africa-Madagascar connection and mammalian migrations. Journal of African Earth Sciences 44: 270-276. https://doi.org/10.1016/j.jafrearsci.2005.12.005

Rabinowitz P. D., Coffin M. \& Falvey D. 1983. - The separation of Madagascar and Africa. Science 220: 67-69. https://doi. org/10.1126/science.220.4592.67

REED F. R. C. 1935. - Notes on the Neogene faunas of Cyprus, 11. Annals and Magazine of Natural History 10 series 15: 1-37.
Renema W., Bellwood D. R., Braga J. C., Bromfield K., Hall R., Johnson K. G., Lunt P., Meyer C. P., Mcmonagle L. B., Morley R. J., O'deA A., TOdD J. A., Wesselingh F. P., Wilson M. E. J. \& PANDOLFI J. M. 2008. - Hopping hotspots: global shifts in marine biodiversity. Science 321: 654-657. https://doi. org/10.1126/science.1155674

Sabarros P. S., Ménard F., Lévénez J. J., KeW-Tai E. \& TerNON J-F. 2009. - Mesoscale eddies influence distribution and aggregation patterns of micronekton in the Mozambique Channel. Marine Ecology Progress Series 395: 101-107. https://doi. org/10.3354/meps08087

SACCO F. 1901. - I molluschi dei terreni terziarii del Piemonte e della Liguria. Parte 29, Clausen Torino, 216 p.

Schouten M. W., De Ruijter W. P. M., Van Leeuwen P. J. \& RIDDERINKHOF H. 2003. - Eddies and variability in the Mozambique Channel. Deep-Sea Research II 50: 1987-2003. https://doi. org/10.1016/S0967-0645(03)00042-0

SMITH E. A. 1885. - Report on the Lamellibranchiata collected by H.M.S. Challenger during the years 1873-76. Report of the Scientific Results of the Voyage of H.M.S. Challenger 1873-76, 13: 1-341.

STUDENCKA B. 1986. - Bivalves from the Badenian (Middle Miocene) marine sandy facies of southern Poland. Palaeontologia Polonica 47: 3-128.

Studencka B., Gontsharovn I. A. \& Popov S. V. 1998. - The bivalve faunas as a basis for reconstruction of the Middle Miocene history of the Paratethys. Acta Geologica Polonica 48: 285-342.

TAshiro M. \& Kozai T. 1988. - Bivalve fossils from the type Monobegawa Group (Part III). Research Reports of the Kochi University 37: 33-64.

TAYlor J. D. \& Glover E. A. 1997. — A chemosymbiotic lucinid bivalve (Bivalvia: Lucinoidea) with periostracal pipes; functional morphology and description of a new genus and species, in WELLS F. E. (ed.), The Marine Flora and Fauna of the Houtman Abrolhos Islands, Western Australia. Western Australian Museum: 335-361.

TAYLOR J. D. \& Glover E. A. 2000. - Nomenclatural rectifications for Indo-Pacific Lucinidae. Journal of Conchology 37: 82.

TAYLOR J. D. \& GlOVER E. A. 2005. — Cryptic diversity of chemosymbiotic bivalves: a systematic revision of worldwide Anodontia (Mollusca: Bivalvia: Lucinidae). Systematics and Biodiversity 3: 281-338. https://doi.org/10.1017/S1477200005001672

TAYlor J. D. \& Glover E. A. 2006. — Lucinidae - the most diverse group of chemosymbiotic molluscs. Zoological Journal of the Linnean Society 148: 421-438.

TAYLOR J. D. \& Glover E. A. 2009. - A giant lucinid bivalve from the Eocene of Jamaica - systematics, life habits and chemosymbiosis (Mollusca: Bivalvia: Lucinidae). Palaeontology 52: 95-109. https://doi.org/10.1111/j.1475-4983.2008.00839.x

TAYLOR J. D. \& GLOVER E. A. 2013. - New lucinid bivalves from shallow and deeper water of the Indian and West Pacific Oceans (Mollusca, Bivalvia, Lucinidae). ZooKeys 326: 69-90. https://doi. org/10.3897/zookeys.326.5786

TAYLOR J. D. \& GlOVER E. A. 2016. — Lucinid bivalves of Guadeloupe: diversity and systematics in the context of the tropical western Atlantic (Mollusca: Bivalvia: Lucinidae). Zootaxa 4196 (3): 301-380. https://doi.org/10.11646/zootaxa.4196.3.1

TaYlor J. D., Glover E. A., Zuschin M., DwOrschaK P. C. \& WAITZBAUER W. 2005. — Another bivalve with dreadlocks: living Rasta lamyi from Aqaba, Red Sea (Bivalvia: Lucinidae). Journal of Conchology 38: 489-497.

Taylor J. D., Glover E. A., Smith L., Dyal P. \& Williams S. T. 2011. - Molecular phylogeny and classification of the chemosymbiotic bivalve family Lucinidae (Mollusca: Bivalvia). Zoological Journal of the Linnean Society 163: 15-49. https://doi. org/10.1111/j.1096-3642.2011.00700.x

TAYlOR J. D., Glover E. A. \& Williams S. T. 2014. - Diversification of chemosymbiotic bivalves: origins and relationships of deeper water Lucinidae. Biological Journal of the Linnean Society 111: 401-420. https://doi.org/10.1111/bij.12208 
Taylor J. D., Glover E. A., Smith L., Ikebe C. \& Wiliams S.T. 2016. - New molecular phylogeny of Lucinidae: increased taxon base with focus on tropical Western Atlantic species (Mollusca: Bivalvia). Zootaxa 4196 (3): 381-398. https://doi.org/10.11646/ zootaxa.4196.3.2

Thomassin B., Andrefouet S., Bouchard J-M., Charpy L., Dinhut V., Quod J-P., Vicente N. \& Wickel J. 2009. Geyser et Zélée: les sommets d'un même volcan sous-marins. Univers Maoré 12: 22-29.

VIADER R. 1951. - New or unrecorded shells from Mauritius and its dependencies. Mauritius Institute Bulletin 3: 127-153.

VOKES H. E. 1939. - Molluscan faunas of the Domengine and Arroyo Hondo formations of the California Eocene. Annals of the New York Academy of Science 38: 1-246. https://doi. org/10.1111/j.1749-6632.1939.tb55368.x
VOKES H. E. 1969a. - Observations on the genus Miltha (Mollusca: Bivalvia) with notes on the type and the Florida Neogene species. Tulane Studies in Geology and Paleontology 7: 93-126.

VOKES H. E. 1969b. - Notes on the fauna of the Chipola Formation - A new species of Eomiltha (Mollusca: Bivalvia). Tulane Studies in Geology and Paleontology 7: 126-130.

WoOdRING W. P. 1925. - Contributions to the geology and palaeontology of the West Indies. Miocene molluscs from Bowden, Jamaica. Pelecypods and scaphopods. Carnegie Institute Washington Publication 366: 222 p., 28 pls.

ZuSCHIN M. \& OLIVER P. G. 2003. - Bivalves and bivalve habitats in the northern Red Sea. The northern Bay of Safaga (Red Sea, Egypt): an actuopalaeontological approach. VI. Bivalvia. Naturhistorisches Museum, Vienna, 304 p. 